NBER WORKING PAPER SERIES

\title{
LONG-RUN RETURNS TO IMPACT INVESTING IN EMERGING MARKETS AND DEVELOPING ECONOMIES
}

\author{
Shawn Cole \\ Martin Melecky \\ Florian Mölders \\ Tristan Reed \\ Working Paper 27870 \\ http://www.nber.org/papers/w27870

\section{NATIONAL BUREAU OF ECONOMIC RESEARCH \\ 1050 Massachusetts Avenue \\ Cambridge, MA 02138} \\ September 2020, Revised July 2021
}

We thank Mohan Manem especially for providing an understanding of the data. Seminar participants at the Harvard Business School Finance Unit, the International Finance Corporation, the World Bank Development Economics Research Group, and the IMF African Department provided helpful comments and questions, along with Adam Fegan, Paddy Carter, Penny Goldberg, Neil Gregory, Victoria Ivashina, Kostas Kollias, Jessica Jeffers, Josh Lerner, Ita MaryMannathoko, Fanele Mashwama, Camilo Mondragón-Vélez, Jacob L. Otto, Tommaso Porzio, Thomas Rehermann, Antoinette Schoar and Jesse Schreger. Anshul Maudar provided excellent research assistance. Cole gratefully acknowledges support from the Division of Research and Faculty Development at Harvard Business School. The views expressed in this paper are those of the authors and do not necessarily represent those of the World Bank Group or the National Bureau of Economic Research. All results have been reviewed to ensure that no confidential information is disclosed. Correspondence may be addressed to Tristan Reed, The World Bank, 1818 H Street NW, MC3-317, Washington DC 20433. Email: treed@worldbank.org

At least one co-author has disclosed additional relationships of potential relevance for this research. Further information is available online at http://www.nber.org/papers/w27870.ack

NBER working papers are circulated for discussion and comment purposes. They have not been peerreviewed or been subject to the review by the NBER Board of Directors that accompanies official NBER publications.

(C) 2020 by Shawn Cole, Martin Melecky, Florian Mölders, and Tristan Reed. All rights reserved. Short sections of text, not to exceed two paragraphs, may be quoted without explicit permission provided that full credit, including $(\mathcal{C}$ notice, is given to the source. 
Long-run Returns to Impact Investing in Emerging Markets and Developing Economies Shawn Cole, Martin Melecky, Florian Mölders, and Tristan Reed

NBER Working Paper No. 27870

September 2020, Revised July 2021

JEL No. G15,O1

\begin{tabular}{|c|c|}
\hline \multicolumn{2}{|c|}{ ABSTRACT } \\
\hline \multicolumn{2}{|c|}{$\begin{array}{l}\text { There is interest in impact investing, the idea of deploying capital to obtain both finar } \\
\text { social returns. But private financial returns are only possible if capital markets are not } \\
\text { integrated, so profit opportunities still exist in certain markets. This proposition is put to } \\
\text { by examining every equity investment made by one of the largest and longest-operatin } \\
\text { investors across } 130 \text { emerging market and developing economies. Since } 1961 \text { this port } \\
\text { performed comparably to public and private equity in the United States, thougl } \\
\text { underperformed since } 2010 \text {. Investments in larger economies have higher returns, an } \\
\text { decline as banking systems deepen and countries relax capital controls. These re } \\
\text { consistent with a core thesis of impact investing that some eligible markets do no } \\
\text { sufficient investment capital. }\end{array}$} \\
\hline Shawn Cole & Florian Mölders \\
\hline Harvard Business School & International Finance Corporation: IFC \\
\hline Baker Library 271 & 2121 Pennsylvania Avenue NW \\
\hline Soldiers Field & Washington, DC 20007 \\
\hline $\begin{array}{l}\text { Boston, MA } 02163 \\
\text { and NBER }\end{array}$ & fmoelders@ifc.org \\
\hline scole@hbs.edu & $\begin{array}{l}\text { Tristan Reed } \\
\text { The World Bank }\end{array}$ \\
\hline Martin Melecky & Development Research Group \\
\hline 1818 H St NW & 1818 H Street NW \\
\hline Washington, DC 20007 & Washington, DC 20433 \\
\hline $\begin{array}{l}\text { USA } \\
\text { mmelecky@worldbank.or }\end{array}$ & treed@worldbank.org \\
\hline
\end{tabular}




\section{Introduction}

There is growing popular interest in impact investing, or deploying financial capital to obtain both financial as well as (measurable) social or environmental returns. The idea is more controversial among philosophers, including economists. Brest, Gilson and Wolfson (2018) argue that an impact investor can make a difference in the world by deploying capital ${ }^{3}$ only if their pursuit of social or environmental goals leads them to invest in projects that would not have been financed otherwise, and, if capital markets are perfectly integrated, the impact investor must therefore obtain lower riskadjusted returns than traditional investors. An alternative perspective argues that there are frictions preventing the flow of capital between markets, that commercially-viable projects fail to receive financing, and that impact investors can promote social objectives while also earning attractive financial returns.

This paper offers evidence in this debate, through analysis of the cash flows associated with every equity investment made by the International Finance Corporation (IFC), a member of the World Bank Group, across 130 emerging market and developing economies (EMDEs). Founded in 1956 with a mandate to "further economic development by encouraging the growth of productive private enterprise in member countries, particularly in less developed areas, " the IFC's understanding of how its investments contribute to improvement in social outcomes is predicated on the view that some eligible markets do not receive sufficient investment capital. Article I of the charter states that "the Corporation shall...assist in financing...in cases where sufficient private capital is not available on reasonable terms."

The IFC's history and approach to investing in EMDEs makes its portfolio uniquely suitable for an investigation of whether certain financial markets offer expected returns that are systematically higher than others. The portfolio is free from sampling problems such as survivorship bias, and is more diversified across countries than either foreign direct investment (FDI) inflows or the MSCI Emerging Market (MSCI EM) index of public equities, both of which have a high concentration

\footnotetext{
${ }^{3}$ Investors could plausibly affect outcomes in other ways as well, such as by insisting on adherence to environmental, social or governance (ESG) criteria, which could affect company performance.
} 
in the largest economies such as China and Brazil. ${ }^{4}$ Relative to the market, the IFC also has a substantially higher share of investment in very poor countries (i.e. those with real GDP per capita of $\$ 1,000$ or less).

A principal concern when comparing investment returns across countries is that differences reflect differences in risk rather than in the risk-adjusted return per se. The data allow us to address this concern comprehensively. First, since we observe the timing of cash flows we are able to measure returns in terms of a public market equivalent (PME), which accounts for both the absolute level of return and the diversification value of payouts that are less correlated with a global risk factor as in the capital asset pricing model (Kaplan and Schoar, 2005; Sorensen and Jagannathan, 2015). Second, since the IFC invests across many sectors, including those considered especially conducive to economic development such as financial institutions (Levine, 2005) and infrastructure (Aschauer, 1989; Roller and Waverman, 2001), we are able to compare returns across countries within production technologies that may vary in their level of non-diversifiable risk. Third, the length of the time series, the longest in existence of which we are aware, provides assurance that differences in average returns across countries are not driven by the realization of non-diversifiable country risk in a few particular years.

The analysis yields three main results. First, ex-post, macroeconomic conditions have material effects, with a 1 percent increase in cumulative annualized real GDP growth over the life of the average investment -8 years - associated with an additional 6.62 percentage points of return on that investment. On the other hand, local currency depreciation worsens the performance, while local inflation (controlling for the depreciation) is associated with higher returns. There is some evidence that improvement in sovereign risk during the investment period improves returns.

Second, certain economy-level covariates measured ex-ante, at the time of investment, do predict performance in a way that is economically and statistically significant: market size and financial system openness and development. More populous EMDEs have higher mean and median returns

\footnotetext{
${ }^{4}$ Our paper is related to a few, employing data on the complete portfolio of a single private equity investor: Gompers and Lerner (1997) study the portfolio of Warberg Pincus and Kerr, Lerner and Schoar (2014) study the portfolio of two prominent angel investment groups, Tech Coast Angels and CommonAngels.
} 
within sectors. Returns fall within economies as they relax capital controls and deepen their banking sectors. These result are inconsistent with the hypothesis of a perfectly integrated international capital market, under which expected financial returns are equalized across economies. Quantitatively, a less integrated market appears to be more important for returns than economic growth, with a one standard deviation decrease in financial openness or banking system depth being associated with an increase in return that is substantially more than is associated with a 1 per-cent increase in cumulative annualized real GDP growth over the life of the average investment. One potential approach a development finance institution could take would be to offer subsidies in lesser developed markets. The finding that the IFC obtains higher returns when capital markets are less developed supports is not consistent with this approach and suggests the IFC may hold to its mandate to offer investments on commercial terms.

Third, in pursuing its strategy, the IFC has achieved competitive returns over the long run. Benchmarking the IFC's equity investment portfolio to the S\&P 500 index (available for our entire sample period), we calculate that the total portfolio has obtained a PME of 1.15, indicating that the portfolio has returned 15 percent more over its life than an equivalently timed investment in the public index would have. Alternative benchmarks yield estimates such as a PME of 1.30 when using the MSCI EM index (after 1988, when the index becomes available). Returns have been lower for investments in the most recent decade, with a PME of 0.70 when using the S\&P 500 and a PME of 0.98 when using the MSCI EM (IFC's internal benchmark). Though only 26 percent of these most recent investments have been realized (and longer holding periods are in these data associated with higher returns) this decline in portfolio performance is consistent with there being fewer opportunities for financial profit as financial markets have become more developed and open. A broader lesson is that in the long-run impact investors could find it challenging to deliver persistent returns at scale when their mandate is to invest in less-integrated markets.

Given that our data include the portfolio of a single investor we do not claim that this performance is representative of the universe of EMDE private equity investments. Nor is it obvious that any other asset owner could replicate the IFC's strategy and returns. The IFC's membership in the World Bank Group for instance offers it protection from expropriation not available to other investors. 
Nonetheless, given it is the only international investor with a portfolio spanning such a large and diverse set of countries and because it co-invests with a number of funds, the portfolio provides a unique view of the return to private investment in EMDEs.

Our paper ties together three strands of literature from finance, development economics, and international macroeconomics. First, we add to the understanding of the financial return to private equity investments in general, and impact investing in particular. While the U.S. private equity industry has been well studied (see Kaplan and Sensoy, 2015, for a comprehensive review) there is very little rigorous evidence available on returns in EMDEs. Lerner, Sorensen, and Stromberg (2009) provide an important exception: they use data from Capital IQ to construct a database of private equity investments around the world starting in about 1990. The authors find that emerging markets comprise a small fraction of total private equity investment, and that country characteristics have some influence on whether funds pursue strategies of financial engineering, governance engineering, and/or operational engineering. While they are unable to measure returns, they examine exits, and find a lower likelihood of success in wealthier countries, and that deals that are undertaken in "hot" markets are more likely to fail. Our paper contributes to this literature by a) providing a history of time series over twice as long, and b) providing the first systematic evidence of returns relative to a benchmark (PME) free of survivorship bias.

A smaller and more recent literature examines the performance of impact investing strategies. Impact investors are defined as those employing a distinctive strategy that contracts on social-benefit outcomes regardless of their returns target (Geczy, Jeffers, Musto, and Tucker, 2021) or as those willing to "pay" for externalities by accepting a below-market return (Barber, Morse, and Yasuda, 2020). We offer the first estimate of the long-run return to an impact investing strategy seeking to provide capital to eligible projects that would not have otherwise received sufficient funding due to imperfectly integrated financial markets.

Second, the portfolio provides the most comprehensive microeconomic evidence yet on the longstanding macroeconomic question of whether international credit frictions exist and their quantitative implications for economic development (Feldstein and Horioka, 1980; Lucas, 1990; Alfaro, 
Kalemli-Özcan and Volosovych, 2008; Chari and Rhee 2020). Previous studies of capital market integration have found high cross-country covariance in the return to public equities (Campbell and Hamao, 1992; Harvey, 1995) and a common marginal product of capital implied by the national accounts in a cross section of countries (Caselli and Feyrer, 2007), concluding that markets appear well integrated and that there are limited barriers to capital moving between countries. In contrast, we examine the return to financial capital in private equity transactions and find evidence of a market segmented by financial sector development, openness and size. Our results, which rely on firm-level data from a much larger sample of economies (including the very poorest), indicate that many firms of the size that typically receive foreign direct investment have faced constraints in finding capital. ${ }^{5}$

Third, we add to an empirical literature on macroeconomic risk through the analysis of the relationship between key macroeconomic variables and private equity returns. Given that equity investments represent real assets, economic theory suggests that equity investments may be used as a hedging instrument against unexpected inflation, and we should therefore expect a positive correlation between performance and inflation. Exchange rate movements are also expected to impact equity returns such as in the case of exporting firms whose competitiveness increases when the home currency depreciates. However in the empirical literature there is some evidence of a negative correlation between equity returns and depreciation (Hau and Rey, 2006). Sovereign risk ratings, which approximate a set of macroeconomic risk factors, have shown to be negatively correlated with equity returns as shown for a set of countries by Brooks et al. (2004) and in the case of Argentina by Hébert and Schreger (2017).

The paper proceeds as follows: Section II provides a conceptual framework, defining impact investing in relation to the model of imperfect international capital market integration offered by the literature on the macroeconomics of development. Section III provides background on the IFC's strategy and operations, the equity portfolio data, and reviews the PME methodology for the measurement of financial returns at the portfolio and investment (firm) level. Section IV describes

\footnotetext{
${ }^{5}$ The average size of a transaction in the IFC's equity portfolio was $\$ 19.5$ million in the most recent decade. Arguments in favor of credit frictions have relied on variable or excessively high marginal products of capital at the firm level among enterprises with assets less than $\$ 400,000$ within a single EDME (Banerjee and Duflo, 2014).
} 
the IFC's allocations and summarizes portfolio and individual investment performance. Section $\mathrm{V}$ reports the main evidence on international capital market integration using the framework of Section II. Section VI shows the evidence on associations of returns and macroeconomic variables and investment duration. Section VII concludes with reference to recent trends in emerging market equity performance, and provides policy advice for private and public sectors.

\section{Conceptual Framework}

In practice, impact investors distinguish themselves from traditional investors through verifiable effort towards both financial profit and social-benefit objectives. ${ }^{6}$ Geczy, Jeffers, Musto, and Tucker (2021) describe how a sample of private impact investment funds contract with employees and portfolio companies. The IFC was created in order to advance economic development and was one of the first to measure social outcomes associated with its investments, and also identifies as an impact investor. ${ }^{7}$ Though the origin of the term "impact investing" is dated around 2007 the concept is much older: Around the year 200 Rabbi Shimon ben Lakish is reported to have said, with regards to helping a needy person, that "a loan is greater than a donation, and a business partnership is greater than all of them" (Levine, 2010, p.291).

The investor's intent to create a social-benefit does not imply the investor creates one. Brest, Gilson and Wolfson (2018) argue that an impact investor can make a difference in the world only if they invest in projects that would not have been financed otherwise (there is term of art for this 'additionality'). If impact investors compete with traditional investors for the same deals, it will be impossible to find such projects. One way to overcome this critique has been to define the impact investor as an asset owner willing to "pay" for potential positive externalities by taking below-market returns (Barber, Morse, and Yasuda, 2020). Many impact investors however still argue they can address social or environmental problems while still earning a competitive financial

\footnotetext{
${ }^{6}$ The Operating Principles for Impact Management require adherence to an investment process that provides asset owners with (verifiable) information on the conduct of fiduciaries in pursuit of social-benefit objectives. Signatories to these Principles include asset managers specialized in "purposeful investing" such as MicroVest Capital Management LLC (\$287 million in assets under management in accordance with the Principles), legacy private wealth managers such as Credit Suisse AG (\$4.2 billion), and government-owned development finance institutions such as the European Bank for Reconstruction and Development (\$51.7 billion). See https:/www.impactprinciples.org/.

${ }^{7}$ See the foreword by CEO Philippe Le Houérou to IFC (2019a).
} 
return; says one "there's no trade off at all” (Noonan, 2018).

The IFC's charter proposes a resolution to this inconsistency by offering an alternative definition of the impact investor: one that provides capital to eligible projects that would not have otherwise received sufficient funding due to imperfectly integrated financial markets. An impact investor's process can make a difference while earning a private financial return only if capital markets are not perfectly integrated, so profit opportunities still exist in certain markets. The existence of international capital market imperfections was a principle on which the World Bank was originally founded (Clemens and Kremer, 2016). Under this definition, impact investors' returns could not be persistent if they are successful in mobilizing capital into less-integrated markets.

In a perfectly integrated international capital market, geography has no systematic effect on the returns investors receive in exchange for their capital. The null hypothesis is purchasing power parity in financial returns. If long-run private returns are available in a particular market, investors will divert their capital there until returns are no longer available (see, e.g., Lucas 1990), either due to competition that bids up entry multiples, or a decline in the marginal product of capital. An empirical test of this model is available in the linear regression equation

$$
r_{i}=r_{0}+X_{c(i)}^{\prime} \beta+\varepsilon_{i}
$$

where $r_{i}$ is the (risk-adjusted) return on asset $i$, and $r_{0}$ is average return on all assets. The vector $X_{c(i)}^{\prime}$ includes various characteristics of country $c$, where the investment is located. The term $\varepsilon_{i}$ is an unrestricted error term. If $\beta \neq 0$ markets are said to be segmented, since the price differs across capital markets (for a case of international product market segmentation, see Goldberg and Verboven, 2001). Conversely, if all countries participate in a perfectly integrated capital market $\beta=0$, and country characteristics would have no effect on the average financial performance of an investment since all investors receive the same price for their capital. In one leading test of this hypothesis, Caselli and Feyrer (2007) calculate the marginal product of capital implied by the national accounts (which is equal to its price in equilibrium) and find it does not vary substantially across countries, or that $\beta=0$. They conclude that "there is no prima facie support for the view 
that international credit frictions play a major role in preventing capital flows from rich to poor countries."

A thesis of impact investing is that frictions do prevent capital flows between certain markets. For instance, the manifesto of the Acumen Fund exhorts the fund "to go where markets have failed." The charter of the IFC posits that in some developing countries, commercially-viable projects fail to receive financing on "reasonable" terms. To make these ideas precise, one could say this thesis is valid if and only if $\beta \neq 0$. When $\beta=0$ the price of capital is the same everywhere and so capital must be available in every market on reasonable terms. Conversely, when $\beta \neq 0$ the equilibrium price of capital is higher in certain markets. If the marginal product of capital diminishes with scale, moving capital from the market in which the price is lower to the one in which it is higher will increase welfare. This could be called impact, or making a difference. Estimation of Equation (1) therefore offers a method to test whether international capital markets are perfectly integrated and also whether it is possible for an investor to have impact in the way described in IFC's original charter.

This conceptual framework shows how economic theory and a cross-section of investments in different markets are used to test whether it is possible to do well by doing good through welfareenhancing arbitrage. This conception of investment impact is consistent with the statements of many impact investment practitioners, and does not require them to sacrifice return to have an impact.

The focus of our analysis is variation (and persistence) of returns across geographies within the portfolio, rather than the total return to the portfolio. Nonetheless, the portfolio return we report is relevant to a strand of literature concerned with whether impact investment strategies achieve returns comparable to public benchmarks. Grey et al. (2016) survey 53 impact investing private equity and venture capital funds, collecting both survey reports of returns and audited financial statements. Using the Russell Microcap 2000 as a comparator, they estimate that a "pooled end-toend aggregate PME calculation for the 170 market-rate-seeking investments in the sample returns a PME gross of fees, expenses and carried interest of 0.98." A potential concern with this study is 
that funds could choose whether to report performance or not; Cochrane (2005) shows that selective reporting can have important effects on estimates of the returns to venture capital investing. Barber, Morse, and Yasuda (2020) obtain data from PreQin on 159 impact funds between 1995 and 2014, and, comparing them to a similar set of non-impact funds, find that impact funds on average achieve a 4.7 percentage point lower IRR. Their paper focuses on impact investing strategies in general, rather than seeking to distinguish between funds that seek to obtain market (commercial) returns and funds that explicitly promise investors lower (concessional) returns. A finding that the average return for both types of these funds - that is, when pooled together-is below market does not necessarily indicate that funds seeking market returns obtain below market returns. By analyzing the portfolio of an investor pursuing economic development and profit goals, we provide the first estimate of the long-run return to an impact investing strategy that seeks market returns. ${ }^{8}$

\section{II.A Background on the International Finance Corporation}

Through its investments the IFC today seeks to contribute to improvement in social and environmental outcomes aligned with the United Nations' Sustainable Development Goals (IFC, 2019b). 185 member countries own and govern the institution, determine its policy, and provide equity capital. The balance sheet size stands at approximately $\$ 99$ billion, of which $\$ 43$ billion are development-related investments and the rest are liquid securities (IFC, 2019c). The carrying value of the equity investment portfolio comprises $30 \%$ of development-related investments.

The IFC charges market-based rates for its loans and seeks market returns on equity investment (IFC, 2019d). ${ }^{9}$ The institution's investment on its own account generally does not exceed $25 \%$ of the value of a project, with other private investors participating through loan syndications, parallel investments, and other instruments. Given its co-investment with others, we view its portfolio as

\footnotetext{
${ }^{8}$ All of IFC's investments may be considered impact investments because they were made with the intent to promote economic development alongside financial profit, as in the Charter. Defining an impact investor by their objective, rather than their allocation to any particular sector, is how impact investing is defined by the industry itself (see, e.g., the Operating Principles for Impact Management, GIIN).

${ }^{9}$ One exception to charging market-based rates comes in the form of a facility for "blended finance" established in 2017. Here, IFC capital is blended with concessional capital from donors in order to allow IFC to earn a commercial return on an investment that would otherwise not be profitable. Such projects are located exclusively in the poorest ("IDA") countries, and the decision to include concessional capital is made before the investment is executed. Our dataset includes four such investments.
} 
potentially informative about the returns available to private investors in the markets in which it operates.

Figure I charts the institution's financial history in three ratios: return on equity (net income/total capital), leverage (total assets/total capital) and administrative expense (non-interest expense/total assets). ${ }^{10}$ The IFC made its first loan in 1957, providing \$2 million to Siemens’ Brazilian affiliate (IFC, 2018). In 1961, the charter was amended to allow holding equity, leading to a surge in equity investment during 1963-64 to about 50\% of total investment (Kapur et al., 1997).By the end of the $1960 \mathrm{~s}$, this share had decreased to $35 \%$. During the $1980 \mathrm{~s}$, the equity share declined to its lowest level to date at $15 \%$, mainly driven by currency crises and global economic turmoil. At the beginning of the 1990 s, the equity share again increased to around $23 \%$, driven by investments in the financial sector and infrastructure. This share remained in the mid- $20 \%$ range until the Global Financial Crisis leading to an increase in the share of equity to total investments above $30 \%{ }^{11}$ Equity investment in private markets has been the basis for growth in the capital base through retained earnings, with realized gains from these investments leading to high points in return on equity seen in Panel A in $1989(\mathrm{RoE}=12.4 \%)$ and in 2005 (20.5\%).

The IFC also raises funds for its operations at international capital markets. As shown in Panel B, the IFC's leverage ratio was 3.6 as at 2019. The extent of borrowing varies substantially across institutions owned by governments that could also be called impact investors because they seek to promote economic development through investment in private firms. For instance, the United Kingdom's CDC Group (2019) has a leverage ratio of 1.0, indicating it does not borrow at all, while the European Investment Bank (2020) has a leverage ratio of 5.8 and the China Development Bank (2017) has a leverage ratio of 12.9 , indicating these banks borrow substantially more relative to their capital base compared to the IFC today. ${ }^{12}$

\footnotetext{
${ }^{10}$ Values used in calculating these ratios are reported in Appendix Table A.

${ }^{11}$ Figure II discussed in Section IV.A. shows the volume of investment over time.

${ }^{12}$ The CDC Group and the European Investment Bank are signatories to the Operating Principles for Impact Management, an affirmation that they identify as impact investors. The leverage ratio reported here is total assets divided by total equity using values from annual reports. For the European Investment Bank, total equity is the sum of accruals and deferred income, provisions, subscribed capital, reserves, and profit for the financial year.
} 
A small literature examines the role of the IFC as an investor and development institution. Dreher et al. (2019) investigate the link between IFC loan allocation and Board membership in the institution, and find a positive relationship between political influence and lending decisions. Taussig and Delios (2015) use data from the IFC's investment in private equity funds to examine the role of local expertise and performance, finding that local expertise improved performance more in countries with weak contract enforcement institutions. Kenny, Kalow, and Ramchandaran (2018) analyze the countries targeted by IFC investment between 2001 and 2016, noting a shift in allocation from low income countries towards middle-income countries. Neither of these papers reports on the returns obtained by the IFC. Desai, Kharas and Amin (2017) study the relationship between IFC project returns and ESG risk factors, though in the period since 2005.

The IFC's long history and broad geographical diversification allow us to paint an unusually rich picture of emerging market private equity investment. It is worth, however, noting several caveats. First, while the IFC's charter prohibits it from taking government guarantees, the IFC's affiliation with the World Bank Group provides additional protection from expropriation. The IFC charter (Article VI, Section 6) states: "Property and assets of the Corporation, wherever located and by whomsoever held, shall be immune from search, requisition, confiscation, expropriation or any other form of seizure by executive or legislative action." Realized returns subject to this immunity may not be representative of what is available to independent investors.

Second, Panel C in Figure I shows IFC's operating expenses at around 2\% of assets during 19641988 , though they have subsequently declined, and are today approximately $1.4 \%$ of assets. These costs include public policy work, and technical assistance for investments, among other things, and also investment costs associated with the debt portfolio, which may be lower than for the equity portfolio alone. Since it is not possible to accurately apportion fixed costs to each investment, and because the IFC engages in significant non-investment activity, such as research and field-building, we analyze portfolio and individual investment performance on a gross basis, without subtracting off operating expenses. Some investments are collective investment vehicles such as private equity funds. 


\section{Data and Measurement}

\section{III.A Investment Financial Performance}

The main data used in this study are the complete set of cash flows to and from all 2,509 equity investments (in companies or funds) beginning at the founding of the IFC in 1956 until June 30th, 2019. ${ }^{13}$ The IFC's equity investments are primarily made through the direct purchase of a minority stake in a company, or participation in a fund as a limited partner. The dataset includes the month of each cash flow, the exact value in US dollars, and the most recent mark-to-market valuation of investments that are still held in the portfolio. Each investment's "vintage year" is defined as the year of first cash flow to the company. Each company is categorized by the "country-of-risk", or the country in which the company generates most of its revenue, as well as by one of 23 sectors (e.g., electric power, food and beverage, finance and insurance). In Appendix Table B, Panel A shows the count of investments by decade and geographic region according to the World Bank Group regional classification and Panel B shows the count of investments by decade and sector. Included among these investments are IFC's interests in individual companies acquired through its participation as a limited partner in funds managed by the IFC Asset Management Corporation (AMC) ${ }^{14}$

We use the cash-flows to calculate the financial performance of the entire portfolio as well as of the investment into each company (or fund). To do this the cash-flow stream is divided into its positive and negative parts, called distributions (dist $(t))$ and contributions (cont $(t)$ ). Distributions are the cash flows returned to IFC either through dividend payments or through the sale of the company's shares. For investments that are still held in the portfolio, we treat the valuation on June 30, 2019 as a positive distribution, as if the investment is liquidated on that date at its fair value, consistent with accounting practice (we also explore how sensitive our results are to these fair value marks, by restricting the sample to only mature investments). Contributions are the IFC's investments into the company, including the payment of management fees in cases when the company is a fund.

\footnotetext{
${ }^{13} \mathrm{We}$ focus on cash flows exclusively related to equity investments, and therefore do not include investments that include both equity and debt components (e.g., convertible loans). We leave analysis of the IFC's credit investments to future research.

${ }^{14}$ Cash flows between portfolio companies of third-party funds in which IFC is a limited partner are not observed.
} 
Our measure of financial return is the Kaplan and Schoar (2005) public market equivalent, defined by

$$
P M E=\frac{\sum_{t} \frac{d i s t(t)}{1+R(t)}}{\sum_{t} \frac{\operatorname{cont}(t)}{1+R(t)}}
$$

where $R(t)$ is the realized total return of the market index from the year of first cash flow $(t=0)$ to the time of the distribution or contribution $(t)$. Sorensen and Jagannathan (2015) motivate the PME as a method to evaluate returns for a CAPM investor whose wealth is held in the index; if the ratio is greater than one, the investor prefers the portfolio to the index. We use the S\&P 500 index as a market reference for comparability to the literature on private equity performance, and because the time series is complete back to our first cash flow in 1961. In some results, we use the MSCI World index and the MSCI Emerging Markets index as alternatives, though these start later in 1970 and $1988 .{ }^{15}$ For comparison, we also report a measure of financial return that does not correct for market risk or the time value of money, total value to paid-in capital, or

$$
T V P I=\frac{\sum_{t} \operatorname{dist}(t)}{\sum_{t} \operatorname{con} t(t)}
$$

which is also known as the investment multiple, or multiple of money. Recall that if the investment has not been fully realized, its fair value on the final date of our data set is treated as a distribution. It is on this basis that the sum of distributions are called "total value."

Our dataset allows us to avoid two forms of selection bias that typically hamper analyses of the performance of an asset class. A first source of selection bias is survivorship bias, such as when successful investments are more likely to appear in a dataset than failures (Carhart, Carpenter, Lynch and Mutso (2002) discuss this in the context of the mutual fund industry). Since our dataset includes all of the IFC's investments - even the write-offs — our analysis will not be affected by such bias. A second source of selection bias is infrequent valuation, such as when an investor values investments only upon a successful initial public offering (IPO) or after the company completes a successive round of fundraising (Cochrane (2005) discusses this in the context of venture capital). Because valuations are positively correlated with these events, ignoring investments that have not

\footnotetext{
${ }^{15}$ Index values are as reported by Bloomberg.
} 
gone public or raised further funds could also lead to an upward bias in average performance. Our estimates are not subject to such bias, first because the majority have already exited, and second because we include the mark-to-market valuations of all unrealized investments on the same date. To check that our results are not driven by mark-to-market valuations that are difficult to determine given the youth of the investment, we restrict the sample to only mature investments, by excluding the 5 most recent vintage years.

\section{III.B Marcoeconomic Covariates}

In our analysis we relate returns to a variety of economy-level covariates such as market size, openness, sovereign risk, and financial development. Two measures of market size, population and GDP per capita, are taken from the World Development Indicators (World Bank, 2019a). Our main measure of financial openness is the index of Chinn and Ito $(2006,2008)$, or the first principal component of dummy variables codifying capital controls including multiple exchange rates, restrictions on current account transactions, restrictions on capital account transactions, and regulatory requirements to surrender export proceeds as reported in the IMF's Annual Report on Exchange Arrangements and Exchange Restrictions. We complement this index with indicators from Fernández et. al. (2015) who codify the IMF's more detailed records, available after 1995, indicating whether foreigners specifically have the right to purchase or sell local equity shares. Our measures of financial development are the standard measures of private sector credit to GDP, indicating banking sector development, and stock market capitalization to GDP, indicating capital markets development. Both are reported in the Global Financial Development Database (World Bank, 2019b).

We also relate returns to several indices used by some investors to assess country risk or investability: (i) a political risk index of the PRS Group, (ii) the Economic Freedom index of the Heritage Foundation, (iii) perceptions of corruption by Transparency International, (iv) Economic Fitness, a dynamic measure of economic complexity that predicts growth (Cristelli et al., 2017), and (v) the Ease of Doing Business Distance to Frontier measure (World Bank, 2019a). Finally, we relate 
returns to several macroeconomic variables reported in the World Development Indicators: (i) real GDP growth, (ii) inflation and (iii) local currency deprecation; (iv) central government debt as a share of GDP as reported by the IMF as well as (v) a sovereign debt rating index produced by Oxford Economics based on an average of ratings by Moody’s, S\&P and Fitch.

\section{Allocations and Investment Performance}

\section{IV.A Location and Timing of IFC's Equity Investments}

First, to provide context for the results on financial performance, we compare the IFC's equity portfolio cash deployed (i.e. contributions, as defined above) to FDI inflows reported by the United Nations Conference on Trade and Development (UNCTAD). FDI inflows are defined as the acquisition of an equity capital stake of 10 percent or more by investors resident in a country different than the one in which the enterprise is located, and hence include most cross-border private equity investment, either by funds or through mergers and acquisitions by firms.

Table I reports the country allocation of IFC investment and FDI in constant dollars broken down by whether countries were classified as "advanced economies" or "emerging market and developing economies" (EMDEs) by the IMF in 2019. All values are in real terms. Overall, IFC equity investment accounts for 0.09 percent of total FDI. Unlike FDI however the IFC has been entirely focused on EMDEs, with 97.7 percent of its cash deployed in current EMDE and 2.3 percent in countries that have since transitioned to advanced economy status such as the Republic of Korea, Greece and the Czech Republic. In contrast, 61.3 percent of FDI has gone to advanced economies where the IFC has never deployed cash, such as the United States (which has received 18 percent of total FDI), the United Kingdom (6.9 percent) and Hong Kong SAR, China (4.3 percent). The IFC also has not deployed equity investment in certain jurisdictions through which some FDI into EMDEs is indirectly channeled (Coppola, Maggiori, Neiman and Schreger, 2020), namely the British Virgin Islands (2.2 percent of total FDI), the Cayman Islands (1.5 percent), and the United Arab Emirates (0.4 percent). 
Figure II shows the value of IFC equity contributions and global FDI inflows for each year in constant US dollars since 1970, the first year the FDI series is available. Overall, IFC investment has grown with FDI, and has been less volatile during certain downturns. While global FDI dropped substantially during the 2001 and 2008 recessions, in 2001 IFC investment actually increased and in 2008 - though falling briefly — it grew substantially in subsequent years while global FDI plateaued. However, the year 2018 did see a large decline in both FDI and equity investment by the IFC. In 2017, the IFC began pursuing a capital increase from shareholders that was approved in 2019, suggesting the institution considered itself still capital constrained at that point.

When examining geographic diversification within EMDEs, we find the IFC's portfolio is more diversified compared to FDI. East Asia and the Pacific together with Latin America and the Caribbean (defined using World Bank regional classifications) attracted 54.0 percent of FDI in EMDEs in which IFC has invested, whereas only 41.4 percent of IFC's investment has gone to these regions. While 11.3 percent of IFC investment has gone to Sub-Saharan Africa, the continent received only 5.3 percent of FDI among countries in which IFC has invested. Looking at the largest FDI destinations in each region, IFC is underweight in China (9.3 percent vs. 19.5 percent of FDI in EMDEs in which IFC has invested), Brazil (6.5 percent vs. 9.0 percent), Nigeria (1.0 percent vs. 1.1 percent), and Saudi Arabia (0.2 percent vs. 2.3 percent), while it is overweight in India (9.6 percent vs. 4.3 percent) and the Russian Federation (5.4 percent vs. 4.6 percent). Standard public equity investment references in EMDEs are even more concentrated than FDI. As of June 2020, more than 75 percent of holdings in the MSCI Emerging Market stock index were located in just five economies: China, Taiwan (China), Korea, India, and Brazil. Compared to both public and private cross-border equity investment in EMDEs, the IFC appears highly diversified.

Kenny, Kalow and Ramachandran (2018) argue that, despite its overall focus on EMDEs, IFC still has a relatively small allocation towards the poorest countries within the group. This is consistent with the presence of fewer investable opportunities in smaller economies, where size is measured by real GDP. The capital asset pricing model (CAPM) predicts that, in equilibrium, each investor holds the world portfolio. If a country's investment opportunities are proportional to GDP, the CAPM investor's allocation will also be proportional to the country's GDP, a result consistent with 
the outsize allocation of FDI to large countries such as the United States and China. Under these assumptions the appropriate test for whether IFC overweights a particular income group (relative to the CAPM investor) is whether its allocation to the group is larger as a share of GDP.

Figure III reports average annual FDI inflows/GDP (Panel A), and average annual IFC investment/GDP (Panel B) as a function of a country's real per capita income in order to conduct such a test. The countries in each group vary over time as real GDP per capita grows, so this figure describes the weighting of investment towards specific income levels rather than specific countries. Relative to our theoretical CAPM benchmark both types of investment appear to overweigh the poorest countries. FDI inflows are on average 1.4 percent of GDP in countries with over $\$ 10,000$ in GDP per capita and 1.9 percent of GDP in countries with less than \$1,000 in GDP per capita, or 35 percent more; IFC exhibits a much steeper slope, investing just 0.0002 percent of GDP in countries with per capita income over $\$ 10,000$, and 0.0044 percent of GDP in countries with less than $\$ 1,000$ in per capita income, or roughly twenty-two times more. IFC also overweights lower middle income countries (i.e., real GDP per capita of $\$ 1,001-\$ 5,000)$ relative to upper middle income countries (i.e., real GDP per capita of $\$ 5,001-\$ 10,000$ ), whereas FDI is slightly lower as a share of GDP in lower middle income countries relative to upper middle income countries. Interestingly, when comparing low income countries (i.e., real GDP per capita $<\$ 1,000$ ) to lower middle income countries, FDI flows relative to GDP are 24 percent greater in low income countries, while the IFC only invests 1 percent more. An explanation for this may be that, relative to FDI, the IFC is underweight in oil, gas and mining, which comprise the bulk of FDI projects in low income countries (Dabla-Norris et al., 2010) but may not satisfy certain ESG criteria, or satisfy IFC's mandate to invest only in projects that could not secure financing from another source.

A final question is how IFC equity investment is timed, relative to both FDI and lending to national governments by the World Bank. We investigate this question using a panel vector autoregression model, in which we regress three country year variables, IFC equity investment/GDP, FDI inflows/GDP and World Bank commitments/GDP on the values of each variable in the past two years, as well as dummies for banking, currency and sovereign debt crises as reported by Laeven and Valencia (2020). The VAR model allows for covariance between the error terms in each of the 
three regression equations to account for the fact that they may be jointly determined as a market equilibrium.

Results are reported in Table II, along with the p-values of Chi-squared tests for four instances of potential Granger causality between the series. The null hypothesis of the first test is that, in column (1), lagged values of FDI/GDP do not predict IFC/GDP, conditional on lagged IFC/GDP; here we cannot reject the null, with $\mathrm{p}=0.498$, indicating there is no evidence that more FDI leads to more IFC investment. The null hypothesis of the second test is that in column (2), lagged values of IFC/GDP do not predict FDI/GDP, conditional on lagged FDI/GDP. Here we also cannot reject the null hypothesis with $\mathrm{p}=0.216$. Together these first two tests suggest there is no significant relationship between FDI inflows and IFC equity investment at the country level. Two additional tests examine the significance of the relationship between IFC equity investment and World Bank commitments to lend to governments. Here we find no evidence that lagged values of either variable predict the other, consistent with limited coordination between activities of the sister institutions in the past, at least as regards equity investment. ${ }^{16}$

Turning to the dummies for different types of crises, it does appear that IFC invests less in times of crisis, though this effect is only statistically significant for instances of sovereign default. The picture is similar for FDI inflows. The World Bank however as expected is significantly more likely to commit to loans in times of banking crises, currency crises, or sovereign debt restructuring, though not during times of sovereign default.

\section{IV.B Financial Performance of IFC's Equity Investments}

We now describe the financial performance of the entire equity portfolio, and of its individual investments, focusing on the PME, which measures performance relative to a counterfactual of an equivalently timed investment into a public market index.

\footnotetext{
${ }^{16}$ Note that the IFC's most recent strategy, promulgated in 2016, does emphasize increased coordination with the World Bank going forward.
} 


\section{IV.B.1 Portfolio Performance}

Table III reports the performance of the entire IFC private equity portfolio, where all cash flows from all investments have been pooled together. Columns of the table report the PME calculated on subsets of investments grouped by earliest vintage year beginning with all investments since the first in 1961, then all investments since 1970, since 1980 and so forth, in order to document the evolution of portfolio returns over time. In addition to PME the performance measure TVPI is reported. The two bottom rows of the table report the number of investments in each vintage year group, as well as the share of investments in that group that have been realized (i.e., have a current holding valuation equal to zero).

Looking first at the PME relative to the S\&P 500, for which the longest series is available, the entire portfolio has achieved a PME $=1.15$ since 1961 . This result indicates that, over the long run, the portfolio has delivered 15 percent more than a counterfactual investment into the US public equity market. IFC's strategy has outperformed public markets over the long run, obtaining returns comparable to many private equity funds in advanced economies as described above. Note the PME relative to the alternative MSCI EM and World indices is systematically higher, consistent with the superior average performance of the S\&P 500 over the long duration of time studied. ${ }^{17}$ For instance, looking at all projects with vintage years after 1990 — shortly after the initiation of the MSCI EM index-IFC achieved a PME $=1.30$ relative to $\mathrm{MSCI} E M$, a PME $=1.23$ relative to MSCI World, and a PME $=1.14$ relative to the S\&P 500 .

Long-run performance appears roughly comparable to the median performance of advanced economy leveraged buyout funds $(\mathrm{PME}=1.16)$ and venture capital funds $(\mathrm{PME}=1.02)$ during the 1980s-2000s, as reported by Harris, Jenkinson, and Kaplan (2014); it is also better than the sample of 170 impact investments made between 2000-2014 studied by Gray et. al. (2016), which achieved a $\mathrm{PME}=1.00$ relative to the S\&P 500. ${ }^{18}$ We emphasize that this ex-post PME does not

\footnotetext{
${ }^{17}$ The MSCI EM outperformed the S\&P 500 only during the 2000s, whereas the S\&P 500 has outperformed MSCI EM in both the 1990s and 2010s.

${ }^{18}$ The PMEs reported in the literature are typically inclusive of management fees by fund managers, while the IFC PME accounts for management fees only in the subset of investments managed indirectly though funds in which the
} 
necessarily imply that the IFC's ex-ante expected return was as high as that demanded by a welldiversified private investor, who for instance could have a different market benchmark to capture systematic risk.

When restricting the portfolio to only investments with vintage years including 2010 and after, the PME has dipped below parity with all three public indices though it still achieved returns comparable to MSCI EM with a PME $=0.98$ relative to that index. Relative to the S\&P 500, the most recent decade of investments delivered a PME $=0.70$. Though IFC's performance has persistently out-outperformed the public benchmarks in previous decades, this recent decline in performance raises the question of whether out-performance will persist.

Several factors could explain the decline in returns. First, far fewer investments in the recent decade have been realized-25.8 percent compared to 69.2 percent of realized investments since 1961 . Newer investments may be held with the expectation that their market valuations will increase. In Section V, we will test this conjecture by testing whether holding duration is associated with higher returns. Second, the significant rally in US equities fueled by cheap credit since the global financial crisis could explain under-performance relative to the S\&P 500. Third, the IFC scaled in the recent decade primarily in more developed middle-income markets, as described by Kenny, Kalow and Ramachandran (2018). Recall that Figure II showed global FDI plateaued in this decade, whereas IFC investment expanded sharply, suggesting perhaps that there could have been fewer investment opportunities available at that time, as financial markets have become more developed and open. This hypothesis could also explain why public equities in emerging markets have broadly underperformed developed markets in the recent decade, for instance in the MSCI index ${ }^{19}$, and why emerging markets also lag developed markets in the Cambridge Associates' index ${ }^{20}$ of private equity and venture capital performance.

A broader lesson could be that in the long-run impact investors find it challenging to deliver persis-

IFC is a limited partner. The long-run PME on collective investment vehicles including private equity fund managers (532 of 2,509 investments) is 0.97 . The portfolio return excluding these vehicles is 1.18 .

${ }^{19} \mathrm{https}: / / \mathrm{www} . \mathrm{msci} . \mathrm{com} /$ documents/10199/c0db0a48-01f2-4ba9-ad01-226fd5678111

${ }^{20} \mathrm{https}: / / w w w . c a m b r i d g e a s s o c i a t e s . c o m / w p-c o n t e n t / u p l o a d s / 2020 / 07 / W E B-2020-Q 1-E x U S-D e v-E M-S e l e c t e d-$ Book.pdf 
tent returns at scale when their mandate is to invest in less-integrated markets. We will test this hypothesis more formally in Section 5 by testing whether capital market openness and developmentwhich move mainly in one direction over time - are associated with higher returns. If closed capital markets and low financial development are a source of excess returns, these returns will not persist as markets open and develop.

A last question is how portfolio performance is affected by specific countries. As described above, the IFC's investment strategy is by design diversified; as a result, long-term outperformance of the S\&P 500 is not driven by any one country. Excluding China, the largest recipient of FDI in EMDEs, yields a PME since inception equal to 1.11, compared to 1.15 for the complete portfolio. Excluding Brazil yields a PME equal to 1.17. Excluding all economies that are classified today by the IMF as advanced, and on this basis could be classified as the success stories of economic development, yields a PME equal to $1.14 .^{21}$ In the next subsection, we investigate this question further by studying how country characteristics are associated with the financial performance of individual investments.

\section{IV.B.2 Individual Investment Performance}

We now summarize the performance of individual investments, which are the basis for the regression analysis in the next section. Appendix Table $\mathrm{C}$ reports average and median values of these return measures by decade.

To illustrate risk in the portfolio, Figure IV plots the density of realized PME (Panel A) and TVPI (Panel B) for all IFC investments (with and without correction for market risk), by decade of initial investment. For the graph, values above 3 were recorded as 3. Decade refers to the vintage year, so even though an investment is classified under the decade in which it originated its return may be based on an exit in a different decade, or the current holding value.

One way to assess the relative risk and reward of each decade is to compare mass to the right of the

\footnotetext{
${ }^{21}$ These economies are the Czech Republic, Estonia, Greece, the Republic of Korea, Latvia, Lithuania, Singapore, the Solvak Republic, Slovenia, and Taiwan (China).
} 
center under each distribution. By this measure, the greatest mass of high return projects (measured by PME) was found in 1961-1969, followed by 2000-2009, followed by 1990-1999. The variance of the distribution appears smallest (not accounting for outliers) when considering the most recent decade 2010-2019. This is expected given the large share of unrealized investments valued at close to their cost. Notably, the worst performance (measured by PME) was for investments originated in 1980-1989; the density function for that decade is skewed further to the left than investments made in 2010-2019. The most recent decade appears also to so far be the lowest risk, with the distribution more tightly clustered around the mean.

IV.B.2.1 Investment Size In Table IV, we report the size distribution of IFC investments, and also the performance of portfolios constructed by grouping together all investments of the same size. Specifically, we classify each company into investment size quartiles by decade, defining size as the nominal value of total cash deployed in the investment. Panel A reports the cutoffs for each quartile in each decade. Prior to 1990, size quartiles were relatively stable across decades, with the cutoff for the bottom quartile ranging from $\$ 0.33$ million to $\$ 0.35$ million, and the cutoff for the top quartile at about $\$ 2.00$ million to $\$ 2.50$ million. The average investment size rose considerably in subsequent decades, with the bottom quartile cutoff rising to $\$ 0.60$ million in 1990-99, \$2.04 million in 200009 , and $\$ 4.00$ million in 2010-19. This growth in average investment size is much more than could be explained by inflation. The share of large investments also increased substantially, with the top quartile cutoff rising to $\$ 6.09$ million in $1990-99$, $\$ 15.45$ million in $2000-2009$, and $\$ 21.76$ million in 2010-19. IFC's portfolio therefore reflects a combination of different investment sizes, with some on the scale of those executed by large private equity funds, and others more on the scale of venture capital investments.

Panel B of Table IV reports the returns to portfolios constructed by pooling cash flows from all investments in the same size quartile together-where quartiles are defined by the cutoffs in Panel A. This ensures that whether an investment is classified as "small" or "large" is defined relative to the time period. Here we see that there is a relationship between investment size and performance, but it is not monotonic. Relative to the S\&P 500, the portfolio of the smallest (1st quartile) 
investments has a $\mathrm{PME}=1.48$, higher than for the overall portfolio. The second quartile portfolio by size has $\mathrm{PME}=1.16$, also slightly higher than the overall portfolio. The largest (4th quartile) investments perform slightly better, with $\mathrm{PME}=1.18$, and the lowest returns are in the third quartile portfolio by size, which has $\mathrm{PME}=1.02$. These results contrast somewhat with the findings of Harris, Jenkinson and Kaplan (2014) who find that, in advanced economies, leveraged buyout funds - which typically do larger deals - have higher average returns than venture capital fundswhich do smaller deals. However, Harris et al. do not report information that would allow us to evaluate differences in sector composition between our and their samples.

\section{Market Segmentation and Country Characteristics}

We now turn to our main analysis, which evaluates the sources of potential segmentation of international capital markets through estimation of Equation (1). To account for the long time series of investments, and potential differences in ex-ante systematic and sectoral risk across investments, we modify this equation into the following:

$$
P M E_{i t}=\tau_{t}+\alpha_{s(i)}+X_{c(i)}^{\prime} \beta+\varepsilon_{i t}
$$

where $i$ indexes the investment, and $t$ indexes the vintage year. The term $\tau_{t}$ is a fixed effect for each vintage year; in a perfectly integrated capital market the return to capital is constant across locations, but may still vary across time. Our returns measure $r_{i t}=P M E_{i t}$ corrects for systemic risk and some time variation in the cost of capital; the time fixed effects therefore capture residual variation in the price of capital not explained by the reference index, in this case the S\&P 500. The term $\alpha_{s(i)}$ is a fixed effect for each sector $s$, included as a control to capture potential differences in ex-ante risk across technologies, which may affect ex-post returns measured by the PME. A fixed effect for collective investment vehicles is included in the sector fixed effects. The vector $X_{c(i)}^{\prime}$ includes various characteristics of country $c$, and the term $\varepsilon_{i t}$ summarizes residual risk. In

estimation we report standard errors clustered at the country level, given potential correlation of residual risk over time.

If all countries participate in a perfectly integrated capital market, then $\beta=0$; country characteris- 
tics would have no effect on the average financial performance of an investment since all investors receive the same price for their capital. When $\beta \neq 0$ markets are segmented by the variables $X_{c(i)}^{\prime}$.

There are several challenges in implementing the test for market integration with $\beta$, however we are able to address because of the unique qualities of this portfolio. First, investors care about riskadjusted returns rather than just mean returns, and risk could vary across countries. To investigate whether risk also varies with country characteristics, we will estimate Equation (1) as a quantile regression, to examine whether the tails of the returns distribution (e.g., 10th percentile, 90th percentile) vary with country characteristics. Second, the different densities of returns illustrated in Figure IV raises the possibility of a selection issue. An investor might overweigh markets with a larger density of high returns in order to equalize returns across markets within the portfolio. In this case, we would fail to reject that markets are perfectly integrated, despite the mean returns in the population of investments in each country being actually different. In the case of the IFC, this challenge is less relevant due to an investment policy that explicitly limits country exposure based on the principal that all IFC member countries have access to IFC's funding, and a desire to manage the concentration of financial risk. ${ }^{22}$ Third, IFC could select different sectors with different levels of ex-ante risk in different countries; for this reason we will include in our empirical specification sector fixed effects, so that cross-country comparisons are within narrow production technologies (e.g., collective investment vehicles, health care, electric power). Fourth, IFC may have achieved its returns due in part to its unique protection from expropriation, or its ability to overcome capital controls. While this protection may affect the total return to the portfolio, since these factors need not affect returns differently across countries, returns variation within the IFC portfolio could still be informative about segmentation of the international capital market in which it operates.

\section{V.A Market Size}

First, we consider segmentation of returns by market size, including in the regression (log) population and (log) GDP per capita, the latter to account for the population's purchasing power. Table V

\footnotetext{
${ }^{22}$ Current policy limits the maximum economic capital exposure to $10 \%$ of IFC's net worth in any country with gross national income greater than $\$ 1.5$ trillion, and which is classified as low risk. Smaller and higher risk economies have smaller exposure limits.
} 
reports the results of this regression, with Column (1) reporting the OLS estimates of Equation (1) and Columns (2)-(6) reporting estimates of a quantile regression, at the 10th, 25th, 50th, 75th and 90th percentiles. The quantile regression allows us to examine differences in risk across markets, rather than just mean returns. Panel A reports a specification with only vintage year fixed effects and Panel B reports a specification with vintage year and sector fixed effects. Panel $\mathrm{C}$ reports the same specification as in Panel B, retaining only mature projects by dropping projects with vintage year of 2015 or later, as a check to see that results are not driven by mark-to-market valuations of the newest projects, which may be more challenging to do accurately.

Looking first at the OLS regression in Column (1) the coefficients on both (log) population and GDP per capita are positive but statistically insignificant in Panel A. They increase in magnitude in Panel B such that the coefficient on (log) population becomes statistically significant at the 10 percent level, though not income. The difference between Panels A and B suggests that some lower observed returns in larger markets can be explained by the composition of sectors, reinforcing the value of sector fixed effects as a control for technological risk. The coefficient on population is no longer statistically significant in Panel $\mathrm{C}$ but well within standard confidence intervals of the coefficient in Column B, suggesting these results are not driven by the most recent investments. Turning to the quantile regressions in Columns (2)-(6), the statistical significance of the effects is much greater, and the coefficient on $(\log )$ GDP per capita also obtains statistical significance at standard levels, consistent with the idea that outliers in the returns distribution make it harder to obtain statistical significance using OLS. Note however downside risk does not appear different across markets, as the coefficients for the 10th percentile regression in column (2) are quite small and insignificant; higher returns in larger economies appear to be driven by the right of the distribution, at the 50th, 75th and 90th percentiles, in columns (4)-(6). This suggests closed markets are not inherently risker, and have more 'home run' investments.

Overall this table provides microeconomic evidence that international capital markets are not perfectly integrated. Systematically higher returns appear to be available in more populous countries; the quantitative magnitude of this effect is also large. For example, the log difference in population between Nigeria and Liberia is roughly $\ln (200)-\ln (5)=3.68$. Multiplying this number by the 
coefficient on population in the OLS regression in Panel B yields 3.68 x $0.038=0.14$, or an additional 14 percentage points in return (relative to the S\&P 500) for each investment. Supposing the investment lasts for 8 years, the average duration of an IFC project reported in Appendix C, yields $\left(1.14^{\left(\frac{1}{8}\right)}-1\right) \times 100=1.65$ percentage points of return per year. Viewed in light of the model in Equation (1) these results suggest that larger markets within our sample of EMDEs are constrained for capital (relative to the perfect integration benchmark) because they have higher average returns that are not bid away by competition. Since Panel B includes sector fixed effects, these effects are not due to a different allocation of investment across sectors in different economies.

\section{V.B Financial Openness and Development}

Investment performance depends on the financial openness and development of a country, which will improve access to capital, lowering average returns. Table VI reports results conditioning on several measures of financial openness and development that may affect foreign and domestic equity investors. Variables are normalized as Z-scores by subtracting off the sample mean and dividing by the standard deviation. Column (1) includes only the financial openness index of Chinn and Ito (2006), Column (2) adds private sector credit to GDP, and Column (3) adds stock market capitalization to GDP. While the coefficients are all negative, as expected, only the coefficient on stock market capitalization to GDP is statistically significant. In Column (4), we include dummies available after 1995 for the specific right of foreigners to buy and sell equity shares. Their effects are not statistically significant. In Column (5), where we drop the 5 most recent years of investments, restricting the sample to only mature investments, and the coefficients also do not differ significantly.

In Column (6), we include dummies for whether a country has British or socialist legal origins, using the classification of La Porta et al. (1999). The omitted category is French or German legal origins (only one country in the sample, the Republic of Korea, is classified as having German legal origins). The British common law tradition is understood to offer equity holders greater protection from expropriation by corporate insiders compared to the French or German civil law traditions. Lerner and Schoar (2005) find that private equity returns and valuations are higher in economies 
with British legal origins and lower in those with socialist legal origins, though their sample is much smaller than ours in terms of the number of countries included. We do not find a statistically significant association between legal origins and financial performance in our sample.

Additional columns provide evidence on the persistence of returns within economies. In Columns (7)-(11) we repeat the specifications in Columns (1)-(5), this time including country fixed effects, which isolate how returns vary over time within countries as the financial system opens and develops. Overall, some but not a great deal of variation is explained by country-specific factors; in Column (1) without country fixed effects the $\mathrm{R}^{2}=0.134$ and in Column (7) it increases to 0.199. Once accounting for country fixed effects, the quantitative magnitude of the coefficients on financial openness and banking system development increases, along with their statistical significance. Using the specification in Column (7) a one standard deviation increase in financial openness reduces return (relative to the S\&P 500) by 25.4 percentage points, or, for an 8 year investment $\left(1.254^{\left(\frac{1}{8}\right)}-1\right) \times 100=2.86$ percentage points per year. In our dataset, between $2000-2001$ as Poland prepared to enter the European Union, its value of the Chinn-Ito openness index increased by approximately 1 standard deviation. In Column (9), a one standard deviation increase in banking sector development reduces return by 46.3 percentage points, or for an 8 year investment, $\left(1.463^{\left(\frac{1}{8}\right)}\right.$ $-1)$ x $100=4.9$ percentage points per year. A one standard deviation increase in private sector credit to GDP is 39 percentage points, approximately the amount of growth experienced by Brazil from 1990 to 2020, or double the growth experienced by Kenya during the same 30 year period. Our interpretation of these results is that capital controls and limited banking system depth prevented capital have prevented capital from flowing to viable projects in developing countries. Were this not the case, we would not observe a change in returns as economies open and develop.

In Column (9) we also see that financial performance increases in markets with deeper capital markets (conditional on financial openness and banking system depth), the opposite of what was found in Column (3). An explanation for this could be that deeper local equity markets aid more efficient pricing of equity investments on exit.

Appendix D reports quantile regressions of the PME on the measure of capital market openness 
and banking system depth, to evaluate how these variables are associated with risk. These regressions show that the decline in return associated with more openness and banking system depth is concentrated in the right of the distribution, and is largest at the 90th percentile, whereas there is no difference in returns at the 10th percentile. This suggests that downside risk does not change with openness and banking system depth, rather the highest return "home run" projects are eliminated from the distribution.

\section{V.C Alternative Risk Factors}

Table VII explores the association between financial performance and five factors that some investors use to gauge country risk or investability, when measured the year before the first cash flow, to capture the effect of information available at the time of investment. A challenge with these data is that the time series and country coverage are often incomplete, reducing the size of the sample. Of these variables, the only one for which we find a significant association is Economic Freedom, more of which is associated with negative returns. This is consistent with the hypothesis that firms in "freer" countries are less capital constrained. The nonsignificance of the political risk, corruption perceptions, and ease of doing business indices suggests that these measures are less relevant for investment analysis than may be assumed, perhaps because even if they are correlated with productivity (e.g., national income) they need not be correlated with the extent of capital market integration, which determines the level of returns.

The results in this section provide the first available evidence on the relationship between financial markets and private equity returns in a large cross section of countries. It is worth relating these findings to what is known about the flows of private equity investments across countries. Lerner et al. (2009) study 76,398 private equity investments made in 1984-2008 that span 123 countries, and, though they do not measure returns, find associations between country characteristics and investment volume as a share of GDP, using similar regressions to those we presented in Table II. These authors report that private equity investment flows more to countries with greater stock market capitalization to GDP and less corruption, though not to markets with less private sector credit to GDP. While their paper studies a different sample of investors, with potentially different 
preferences than the IFC, one way to reconcile these results with our own is that the greatest volume of investment may not necessarily go to the markets with highest returns; indeed, returns could be highest in markets with less private sector credit to GDP precisely because there is less investment in those markets.

\section{Macroeconomic Variables, Investment Duration, and In- vestment Performance}

We now consider how returns vary with the macroeconomic variables that typically appear in a small open-economy macro model used for country risk analysis, namely real GDP growth, inflation, and local currency depreciation. We also consider central government debt to GDP and the sovereign risk rating as proxies for the country risk premium. In Table VIII, we consider how these variables relate to performance when evaluated ex-ante, in the year before first cash flow. The regression here is identical to Equation (2). In Table IX, we consider how annualized changes in these variables between the year of first cash flow and the last cash flow are associated with returns. This is a different specification, which does not investigate market segmentation, but rather associations of ex-post macroeconomic outcomes with returns.

Overall, Table VIII shows that macroeconomic variables measured in the year before investment have a less significant association with performance. The only significant coefficient (at 10 percent) is on real GDP growth in Column (6). Notably, the effects of central government debt as a share of GDP and the sovereign rating are estimated as precise zeros. Our interpretation of these results is that macroeconomic variables at time of investment do not have great predictive power over which capital markets are integrated with the international market, and so provide limited information about subsequent returns.

Table IX shows the effects of changes in macroeconomic variables over the life of the investment. Such macro dynamics have significant predictive power for investment performance. In Column (1), one additional percentage point of GDP growth in each year of the investment is associated 
with an increase in PME of 0.066 percentage points, or an additional 6.6 percentage points in return over the life of the investment. This is natural as GDP growth reflects broad-based productivity growth or increase in the labor supply, including for IFC investees. In Column (2), we see that investment performance declines significantly if the local currency depreciates over the course of the investment. Recall that financial returns are all measured in US dollars, and so depreciation of the currency implies a lower valuation of the firm's cash flow. In contrast, in Column (3), we see that faster growth of domestic prices (measured by the local currency GDP deflator) reduces performance, but this effect is not statistically significant. In Column (4), which includes together all three of the variables in the previous three columns, we see that the associations with currency depreciation and local currency inflation almost completely cancel each other out on average, consistent with what would be expected with a freely floating exchange rate. Real GDP growth remains a significant predictor of returns (at 10 percent significance), though its magnitude is reduced somewhat to 4.3 additional percentage points of return for an additional 1 percent of cumulative annualized GDP growth over the course of the investment.

In Column (5), we see a negative association of investment performance and growth in the stock of government debt relative to GDP and in Column (6) we see a negative association between returns and deterioration in the sovereign debt rating. However, when these variables are combined with GDP growth, inflation, and local currency depreciation in Columns (7) and (8) these variables all lose statistical significance, though these specifications also have a smaller number of observations. As ratings are largely determined by a small number of country risk factors such as GDP growth and inflation (Cantor and Packer, 1996) this is not surprising.

\section{VI.A Duration}

Finally, in Table X we examine the association between investment financial performance and holding duration, where duration is measured as the number of years between the first and last cash flow. In this portfolio the 25 th percentile of holding duration is 4 years, the 50 th percentile is 7 years and the 75th percentile is 11 years. Column (1) reports that an additional year of duration increases PME by 0.04 , and this result is statistically significant at one percent. Column (2) estimates this 
relationship using a spline function, which allows the slope between PME and duration to differ between three intervals: less than 5 years, between 5 and less than 10 years, and 10 years or more. Here, the slope remains positive and statistically significant at standard levels in all three intervals, though the slope becomes less steep after 10 years. In Columns (3) and (4) these specifications are replicated restricting the sample only to realized investments, with no significant change in the estimated coefficients. A potential explanation for the outperformance of private equity investments relative to public markets is that outperformance reflects a liquidity premium - higher returns in exchange for a longer holding duration. These results are consistent with the existence of such a premium. They are also consistent with the idea of private returns to 'patient' capital, a theme among impact investors.

\section{Conclusions}

Our analysis of the IFC portfolio provides insight for any international investor who contemplates investing in emerging market and developing economies to realize an above market return on equity. Imperfect integration of international capital markets appears to have left available especially attractive opportunities in countries with less developed banking systems and capital controls, as well as in larger economies, creating scope for both financial profit and a social impact.

It is an open question whether alternative impact strategies, which might for example focus on a specific sector, and could measure social or environmental outcomes associated with investments, could expect similar returns. Nor is it certain that opportunities the IFC has exploited will be available in the future. Notably, when restricting the portfolio to only investments with vintage years including 2010 and after, performance has been considerably worse than the S\&P 500, and on par with the MSCI EM index, which IFC had previously outperformed, and grew very little in absolute terms during the decade. A candidate explanation for this trend could be that international capital markets are now better integrated than they were when IFC was founded. Economic development is a linear processes. Economies rarely close after opening, and private sector credit as a share of GDP grows more with development, leaving fewer and fewer opportunities to go where other investors do not. 
This observation highlights an irony associated with the thesis of impact investing elaborated this paper: if impact investors seeking expand access to capital in less integrated markets are successful, their financial performance will not persist. While persistence of returns has been the grail of traditional private equity fund managers - making it a central object of study in the literature on private equity performance - for impact investment funds it may be even more difficult to establish as a long term goal. The only route to persistence can to identify or create new markets where there will be limited competition to provide finance, for instance for new production technologies, or untested business models.

The data posit a model of decreasing returns to scale in impact investing. Smaller investments perform better, and when held for a longer time period. For IFC, an expansion at $\$ 2$ billion in new equity investment per year coincided with deterioration in financial performance. The contemporaneous collapse in FDI, which favored middle-income economies, is consistent with a decline in available investment opportunities in those economies where the IFC continued to scale up. In the future it may be more profitable to invest $\$ 1$ billion a year or less, targeting smaller, more profitable deals in markets where capital is scarce.

Our analysis has implications for policy makers seeking to attract investment to their countries. In the neoclassical model described by Lucas (1990) that we verify here, as capital markets become more integrated, more capital will flow but expected returns will fall. This implies it could be even harder for economies to attract additional capital, since the 'home-run' opportunities (e.g., at the 90th percentile of the returns distribution) will no longer be available. GDP growth is an important factor in determining the financial performance of investment; as expected returns fall due to increased openness, it will be even more important for economies to provide solid economic growth if they wish to attract more investors. Once capital markets are perfectly integrated, finance can only follow growth, not the other way around.

Our results on depreciation point to one practical public policy that could contribute to the integration of international capital markets in a world with a dominant currency. Given the substantial effects of ex-post currency depreciation observed on US dollar returns, there could be a benefit 
from policies that enhance exchange rate stability, and initiatives that provide external convertibility of local currencies through products such as swaps and forward contracts, especially when those currencies are not widely traded. The Currency Exchange Fund (TCX) is an example of such an initiative by some development finance institutions. Such insurance mechanisms are utilized most frequently in debt rather than equity transactions, but nonetheless may help investors consider more volatile developing economies as viable investment opportunities, including those with the greatest capital shortages. 


\section{References}

Alfaro, Laura, Şebnem Kalemli-Özcan, and Vadym Volosovych. 2008. "Why doesn’t capital flow from rich to poor countries? An empirical investigation." The Review of Economics and Statistics, 90 (2): 347-368.

Aschauer, David A. 1989. "Is public expenditure productive?" Journal of Monetary Economics, 23 (2): 177-200.

Banerjee, Abhijit V., and Esther Duflo. 2014. "Do firms want to borrow more? Testing credit constraints using a directed lending program." Review of Economic Studies, 81 (2): 572-607.

Barber, Brad, Adair Morse and Ayako Yasuda. 2020. "Impact Investing” Journal of Financial Economics, forthcoming.

Brest, Paul, Ronald J. Gilson, and Mark A. Wolfson. 2018. "Essay: How Investors Can (and Can't) Create Social Value.” J. Corp. L. 44: 205.

Brooks, Robert, Robert Faff, David Hillier, and Joseph Hillier. 2004. "The national market impact of sovereign rating changes." Journal of Banking \& Finance 28 (1): 233-250.

Campbell, John Y., and Yasushi Hamao. 1992. "Predictable stock returns in the United States and Japan: A study of long $\square$ term capital market integration." The Journal of Finance, 47 (1): 43-69.

Cantor, Richard and Frank Packer. 1996. "Determinants and Impact of Sovereign Credit Ratings." FRBNY Economic Policy Review, 2 (2): 37-54.

Carhart, Mark M., Jennifer N. Carpenter, Anthony W. Lynch, and David K. Musto. 2002. "Mutual fund survivorship." The Review of Financial Studies, 15 (5): 1439-1463.

Caselli, Francesco, and James Feyrer. 2007. "The marginal product of capital." The Quarterly Journal of Economics, 122 (2): 535-568.

CDC Group. 2019. “Annual Accounts 2019: Towards a decade of Action.”

Chari, Anusha, and Jennifer S. Rhee. 2020. "The Return to Capital in Capital-Scarce Countries." National Bureau of Economic Research Working Paper No. 27675.

China Development Bank. 2017. "2017 Annual Report”

Chinn, Menzie D., and Hiro Ito. 2006. "What matters for financial development? Capital controls, institutions, and interactions." Journal of Development Economics, 81 (1): 163-192.

Chinn, Menzie D., and Hiro Ito. 2008. "A new measure of financial openness." Journal of Comparative Policy Analysis, 10 (3): 309-322.

Clemens, Michael A., and Michael Kremer. 2016. "The new role for the World Bank." Journal of Economic Perspectives, 30(1), pp.53-76.

Cristelli, Matthieu, Andrea Tacchella, Masud Cader, Kirstin Roster, and Luciano Pietronero. 2017. "On the predictability of growth." World Bank Policy Research Working Paper No. 8117. 
Cochrane, John H. 2005. "The risk and return of venture capital." Journal of Financial Economics, 75(1): 3-52.

Coppola, Antonio, Matteo Maggiori, Brent Neiman, and Jesse Schreger. 2020. "Redrawing the Map of Global Capital Flows: The Role of Cross-Border Financing and Tax Havens", NBER Working Paper No. 26855.

Dabla-Norris, Era, Jiro Honda, Amina Lahreche, and Geneviève Verdier. 2010. "FDI flows to low-income countries: Global drivers and growth implications." IMF Working Papers: 1-38.

Dreher, Axel, Valentin F. Lang, and Katharina Richer. 2019. “The political economy of International Finance Corporation lending." Journal of Development Economics 140: 242-254.

Desai Raj M., Homi Kharas and Magdi Amin. 2017. "Combining Good Business and Good Development: Evidence from IFC Operations" Global Economy and Development Working Paper No. 103. May 2017.

European Investment Bank. 2020. Financial Report 2019

Feldstein, Martin, and Charles Horioka. 1980. "Domestic Saving and International Capital Flows", Economic Journal, 90(358): 314-329

Fernández, Andrés, Michael W. Klein, Alessandro Rebucci, Martin Schindler, and Martin Uribe. 2015. "Capital control measures: A new dataset." IMF Economic Review, 64 (3): 548-574.

Geczy, Christopher, Jessica S. Jeffers, David K. Musto, and Anne M. Tucker. Forthcoming. "Contracts with (social) benefits: the implementation of impact investing." Journal of Financial Economics.

Goldberg, Pinelopi K., and Frank Verboven. 2001. "The evolution of price dispersion in the European car market." The Review of Economic Studies 68(4): 811-848.

Gompers, Paul A., and Josh Lerner. 1997. "Risk and reward in private equity investments: The challenge of performance assessment." The Journal of Private Equity: 5-12.

Gray, Jacob, Nick Ashburn, Harry Douglas, Jessica Jeffers, David K. Musto, and Christopher Geczy. 2016. "Great expectations: Mission preservation and financial performance in impact investing." Wharton Social Impact Initiative.

Harris, Robert S., Tim Jenkinson, and Steven N. Kaplan. 2014. "Private equity performance: What do we know?" The Journal of Finance 69 (5): 1851-1882.

Harvey, Campbell R. 1995. "Predictable risk and returns in emerging markets." The Review of Financial Studies, 8(3): 773-816.

Hau, Harald and Hélène Rey. 2006. "Exchange Rates, Equity Prices, and Capital Flow," Review of Financial Studies, 19 (1), 273-317.

Hébert, Benjamin, and Jesse Schreger. 2017. "The Costs of Sovereign Default: Evidence from Argentina." American Economic Review, 107 (10): 3119-45. 
International Finance Corporation. 2018. "Blended Finance - A Stepping Stone to Creating Markets," EMCompass, Note 51. Washington, DC.

International Finance Corporation. 2019a. "Creating Impact: The Promise of Impact Investing," Technical Report. Washington, DC.

International Finance Corporation. 2019b. "IFC's Strategic Alignment with the Sustainable Development Goals" available online. Washington, DC.

International Finance Corporation. 2019c. “Annual Report 2019 - Investing for Impact,” Report. Washington, DC.

International Finance Corporation. 2019d. "Information Statement," available online. Washington, DC.

Kaplan, Steven and Antoinette Schoar. 2005. "Private Equity Performance: Returns, Persistence and Capital Flows," The Journal of Finance, 60(4), 1791-1823.

Kaplan, Steven and Berk Sensoy. 2015. "Private Equity Performance: A Survey," Annual Review of Financial Economics, 7: 597-614.

Kapur, Devesh, John P. Lewis, and Richard Webb. 1997. "The World Bank - Its First Half Century," Brookings Institution Press, Washington D.C.

Kenny, Charles, Jared Kalow and Vijaya Ramachandran. 2018. "Inside the Portfolio of the International Finance Corporation: Does IFC Do Enough in Low-Income Countries?" Center for Global Development Policy Paper 115.

Kerr, William R., Josh Lerner, and Antoinette Schoar. 2014. "The consequences of entrepreneurial finance: Evidence from angel financings." The Review of Financial Studies 27(1): 20-55.

Kovner, Anna and Josh Lerner. 2015. "Doing Well by Doing Good? Community Development Venture Capital", Journal of Economics and Management Strategy 24, 643-663.

Laeven, Luc, and Fabian Valencia. 2020. "Systemic Banking Crises Database II.", IMF Economic Review: 1-55.

La Porta, Rafael, Florencio Lopez-de-Silanes, Andrei Shleifer, and Robert Vishny. 1999. "The quality of government." The Journal of Law, Economics, and Organization 15(1): 222-279.

Lerner, Josh, and Antoinette Schoar. 2005. "Does legal enforcement affect financial transactions? The contractual channel in private equity." The Quarterly Journal of Economics 120(1): 223-246.

Lerner, Josh, Morten Sorensen, and Per Stromberg. 2009. "What Drives Private Equity Activity and Success Globally", manuscript, Stockholm School of Economics.

Levine, Aaron, ed. 2010. The Oxford Handbook of Judaism and Economics. New York, NY: Oxford University Press.

Levine, Ross. 2005. "Finance and Growth: Theory and Evidence." In Philippe Aghion and Steven Durlauf (eds.) Handbook of Economic Growth, 865-934. 
Noonan, Laura. 2018. "Young Asians pursue impact investing that makes profit at home." The Financial Times. Singapore: March 18, 2018.

Lucas, Robert. 1990. "Why doesn't capital flow from rich to poor countries," American Economic Review, 80(2): 92-96.

Roller, Lars-Hendrik, and Leonard Waverman. 2001. "Telecommunications Infrastructure and Economic Development: A Simultaneous Approach." American Economic Review, 91 (4): 909923.

Sorensen, Morten, and Ravi Jagannathan. 2015. "The public market equivalent and private equity performance.” Financial Analysts Journal 71(4): 43-50.

Taussig, Markus, and Andrew Delios. 2015. "Unbundling the Effects of Institutions on Firm Resources: The Contingent Value of Being Local in Emerging Economy Private Equity." Strategic Management Journal, 36, 1845-1865.

World Bank. 2019. "World Development Indicators"

World Bank. 2019. "Global Financial Development Database (GFDD)" 
Figure I: Key financial ratios of the International Finance Corporation. Values of assets prior to 2001 are not directly comparable with those after due to a change in accounting standards requiring derivatives to be held at fair rather than book value (FAS No. 133).
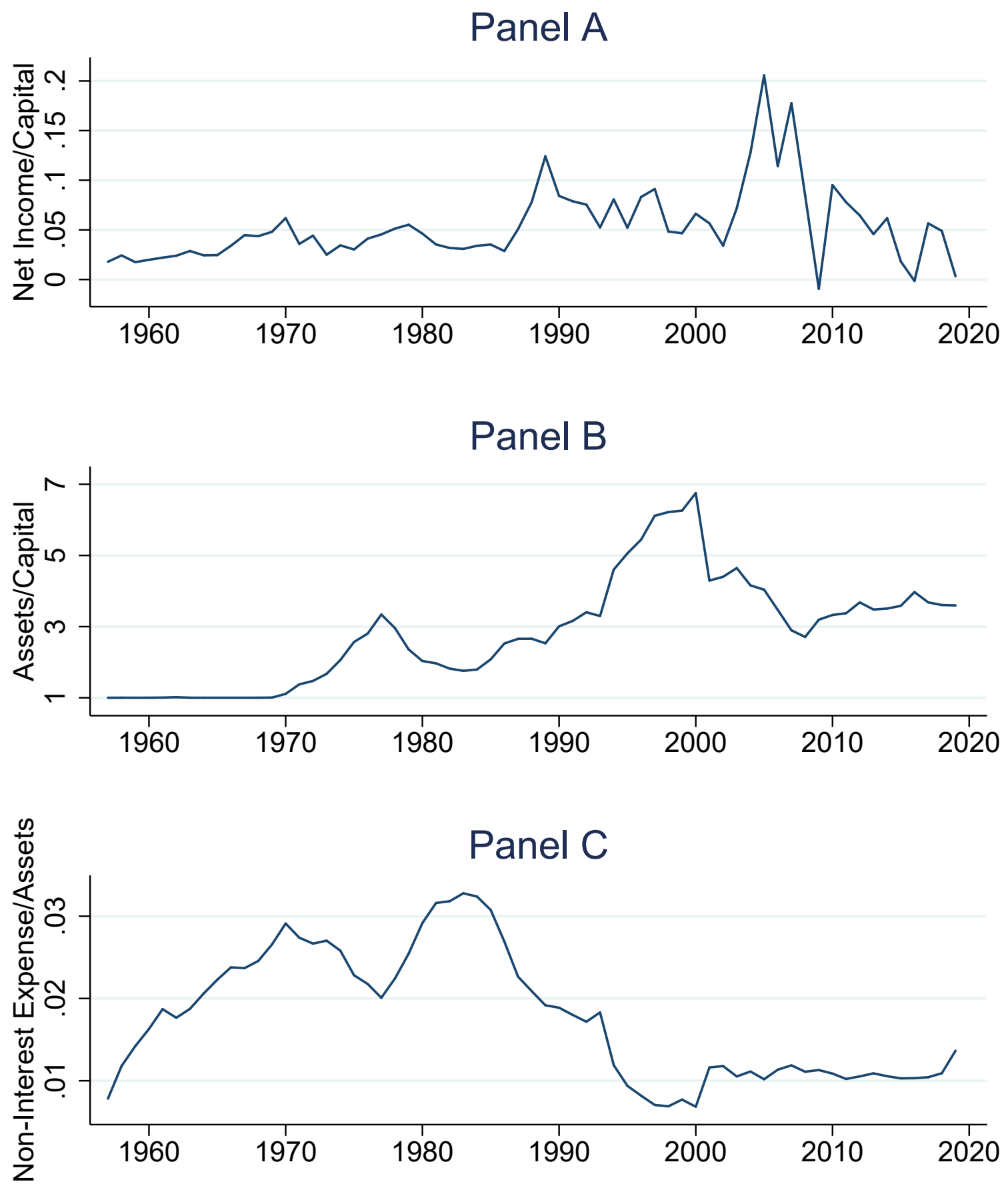

Source: IFC annual reports 
Figure II: The growth of international private equity investment

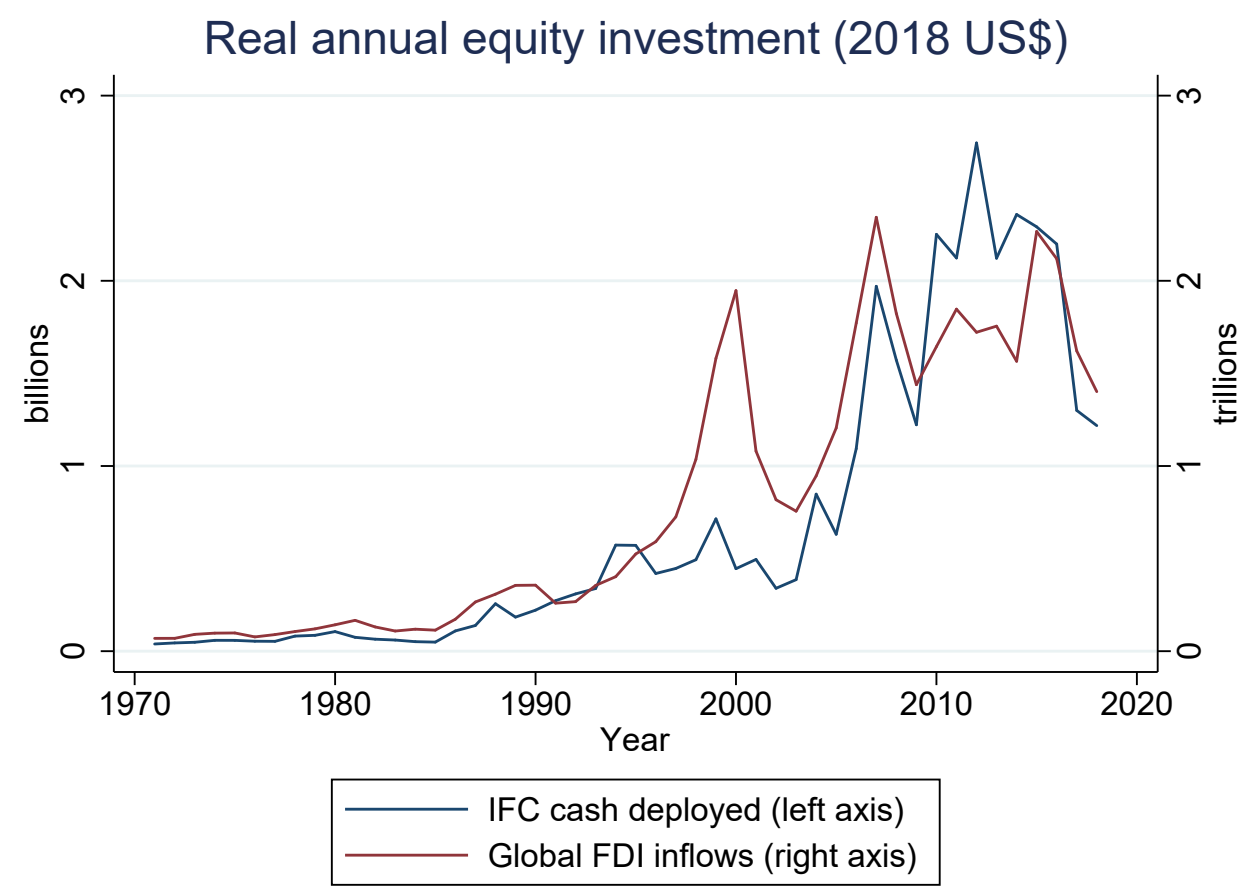

Sources: UNCTAD, IFC equity cash flows

Figure III: Comparison of FDI inflows and IFC equity investment as a share of national income

FDI inflows and IFC equity investment by GDP per capita

Panel A

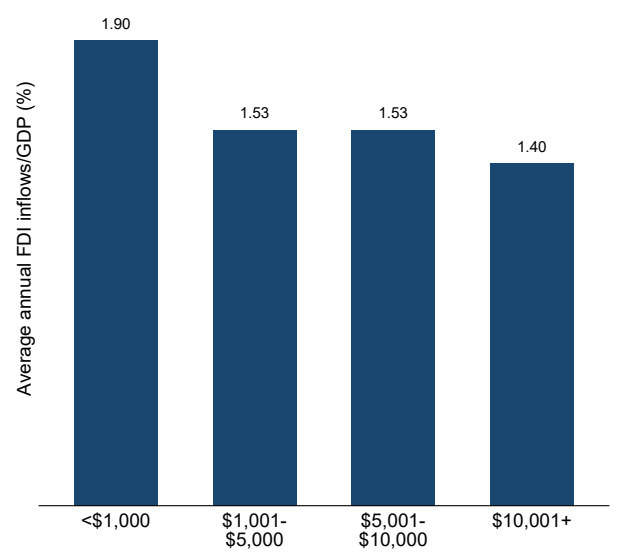

Panel B

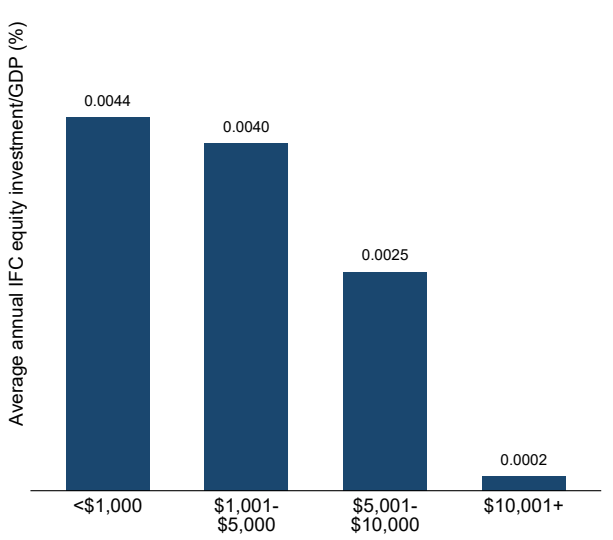

Sources: UNCTAD, IFC equity cash flows, World Development Indicators. 
Figure IV: Individual equity investment performance by decade
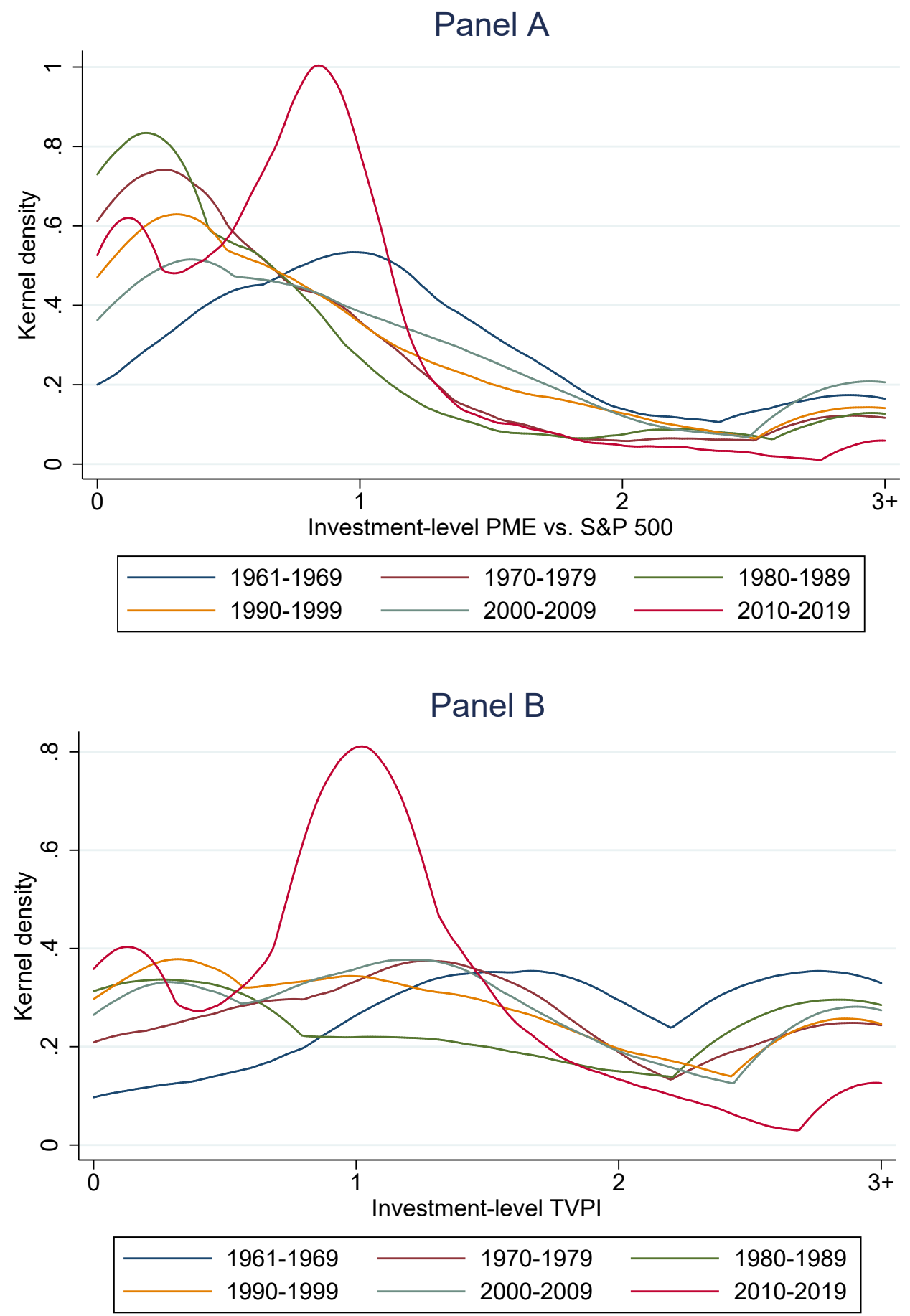

Source: IFC equity cash flows

Note: For the graph, values above 3 were recorded as 3 . 
TABLE I: Geographic distribution of IFC equity investment compared to foreign direct investment. This table presents IFC equity investment and global FDI flows by region. Advanced economies are as classified by the IMF as of 2019. Advanced economies with IFC equity investments are, in descending order of real cash deployed: the Republic of Korea, Greece, Czech Republic, Slovak Republic, Latvia, Singapore, Estonia, Slovenia, Lithuania and Taiwan (China). Brazil; China, Russian Federation, Nigeria, India and Saudi Arabia are the largest FDI destinations in their regions. The United States; United Kingdom; and Hong Kong SAR (China) are the world's three largest FDI destinations among advanced economies. The British Virgin Islands, Cayman Islands and United Arab Emirates are the three largest Emerging Market and Developing Economies FDI destinations without IFC cash deployed. World region IFC projects are grouped under Emerging Market and Developing Economies. Regional IFC projects are grouped under their region. FDI inflows from UNCTAD up to 2018. Values are 2018 dollars, converted from nominal dollars using the US GDP deflator.

\begin{tabular}{|c|c|c|c|c|c|c|}
\hline & \multicolumn{2}{|c|}{ IFC equity investment since 1956} & \multicolumn{3}{|c|}{ FDI inflows since 1970} & $\mathrm{IFC} / \mathrm{FDI}$ \\
\hline Emerging Market and Developing Economies & 33.77 & $97.7 \%$ & 11.33 & $85.9 \%$ & $29.1 \%$ & $0.30 \%$ \\
\hline Latin America and the Caribbean & 8.01 & $23.2 \%$ & 3.45 & $26.2 \%$ & $8.9 \%$ & $0.23 \%$ \\
\hline East Asia and the Pacific & 6.28 & $18.20 \%$ & 3.67 & $27.80 \%$ & $9.40 \%$ & $0.17 \%$ \\
\hline China & 3.22 & $9.30 \%$ & 2.57 & $19.50 \%$ & $6.60 \%$ & $0.13 \%$ \\
\hline Europe and Central Asia & 6.37 & $18.40 \%$ & 2.02 & $15.30 \%$ & $5.20 \%$ & $0.32 \%$ \\
\hline Russian Federation & 1.85 & $5.40 \%$ & 0.61 & $4.60 \%$ & $1.60 \%$ & $0.30 \%$ \\
\hline India & 3.31 & $9.60 \%$ & 0.56 & $4.30 \%$ & $1.40 \%$ & $0.59 \%$ \\
\hline Middle East and North Africa & 3.22 & $9.30 \%$ & 0.81 & $6.10 \%$ & $2.10 \%$ & $0.40 \%$ \\
\hline Saudi Arabia & 0.08 & $0.2 \%$ & 0.31 & $2.3 \%$ & $0.8 \%$ & $0.03 \%$ \\
\hline World Region & 1.54 & $4.5 \%$ & - & - & - & - \\
\hline Advanced Economies & 0.78 & $2.3 \%$ & 1.87 & $14.1 \%$ & $4.8 \%$ & $0.04 \%$ \\
\hline Korea, Rep. & 0.30 & $0.9 \%$ & 0.29 & $2.2 \%$ & $2.2 \%$ & $0.10 \%$ \\
\hline Greece & 0.20 & $0.6 \%$ & 0.08 & $0.6 \%$ & $0.6 \%$ & $0.25 \%$ \\
\hline Czech Republic & 0.18 & $0.5 \%$ & 0.17 & $1.3 \%$ & $1.3 \%$ & $0.11 \%$ \\
\hline Advanced Economies & & & 23.86 & & $61.3 \%$ & \\
\hline United States & & & 7.02 & & $18.0 \%$ & \\
\hline United Kingdom & & & 2.68 & & $6.9 \%$ & \\
\hline Hong Kong SAR (China) & & & 1.68 & & $4.3 \%$ & \\
\hline \multicolumn{7}{|c|}{42} \\
\hline TOTAL & & & 38.95 & & $100.0 \%$ & $0.09 \%$ \\
\hline
\end{tabular}


TABLE II: IFC equity investment strategy described by a panel vector autoregression. An observation is a country year. IFC/GDP refers to IFC equity portfolio cash deployed as a share of GDP in a given country year. FDI/GDP refers to FDI inflows as a share of GDP. WB/GDP refers the value of board approved World Bank lending committments (through either the International Development Association and the International Bank for Reconstruction and Development) as a share of GDP. Crises and sovereign debt restructuring are as reported by Leaven and Valencia (2020). Standard errors are clustered at the country level. ${ }^{* * *} \mathrm{p}<0.01,{ }^{* *} \mathrm{p}<0.05,{ }^{*} \mathrm{p}<0.1$

\begin{tabular}{|c|c|c|c|}
\hline & (1) & (2) & (3) \\
\hline & $(\mathrm{IFC} / \mathrm{GDP}) \times 100$ & FDI/GDP & WB/GDP \\
\hline \multirow[t]{2}{*}{$(\mathrm{IFC} / \mathrm{GDP}) \times 100(\mathrm{t}-1)$} & $0.046^{*}$ & 0.056 & 0.006 \\
\hline & $(0.027)$ & $(0.062)$ & $(0.010)$ \\
\hline \multirow[t]{2}{*}{$(\mathrm{IFC} / \mathrm{GDP}) \times 100(\mathrm{t}-2)$} & $0.055^{*}$ & 0.008 & 0.005 \\
\hline & $(0.032)$ & $(0.038)$ & $(0.006)$ \\
\hline \multirow[t]{2}{*}{ FDI/GDP (t-1) } & 0.005 & -0.078 & 0.001 \\
\hline & $(0.005)$ & $(0.691)$ & $(0.002)$ \\
\hline \multirow[t]{2}{*}{ FDI/GDP (t-2) } & 0.003 & -0.098 & 0.000 \\
\hline & $(0.003)$ & $(0.370)$ & $(0.001)$ \\
\hline \multirow[t]{2}{*}{ WB/GDP (t-1) } & 0.075 & -0.418 & 0.005 \\
\hline & $(0.103)$ & $(0.472)$ & $(0.143)$ \\
\hline \multirow[t]{2}{*}{$\mathrm{WB} / \mathrm{GDP}(\mathrm{t}-2)$} & -0.001 & -0.317 & 0.101 \\
\hline & $(0.031)$ & $(0.378)$ & $(0.093)$ \\
\hline \multirow[t]{2}{*}{ Banking Crisis $(=1)$} & -0.001 & -0.006 & $0.003 * * *$ \\
\hline & $(0.001)$ & $(0.010)$ & $(0.001)$ \\
\hline \multirow[t]{2}{*}{ Currency Crisis $(=1)$} & -0.001 & -0.016 & $0.004 * * *$ \\
\hline & $(0.001)$ & $(0.017)$ & $(0.001)$ \\
\hline \multirow[t]{2}{*}{ Sovereign Default $(=1)$} & $-0.003 *$ & $-0.018 * *$ & -0.000 \\
\hline & $(0.002)$ & $(0.008)$ & $(0.002)$ \\
\hline \multirow[t]{2}{*}{ Sovereign Debt Restructuring $(=1)$} & -0.002 & -0.011 & $0.005 * *$ \\
\hline & $(0.002)$ & $(0.009)$ & $(0.002)$ \\
\hline Observations & 7,686 & 7,686 & 7,686 \\
\hline \multicolumn{4}{|l|}{ p-values of Chi-squared tests: } \\
\hline H0: Coefficients on both lags of FDI/GDP $=0$ in Column (1) & & & 0.498 \\
\hline H0: Coefficients on both lags of IFC/GDP $=0$ in Column (2) & & & 0.216 \\
\hline H0: Coefficients on both lags of WB/GDP $=0$ in Column (1) & & & 0.584 \\
\hline H0: Coefficients on both lags of IFC/GDP $=0$ in Column (3) & & & 0.715 \\
\hline
\end{tabular}


TABLE III: Financial performance of the IFC private equity portfolio as of June 30, 2019. The public market equivalent (PME) is measured following Kaplan and Schoar (2005) as the ratio of cash in (disbursements) to cash out (client capital calls), where each series is discounted according to a public market index. The discount rate is given by the total return of the index, including dividends and price appreciation. Cash flows and the index value are observed on the last date of each month. For investments with non-zero holding valuation, the fair value is treated as a positive cash flow in June 30,2019, as if the investment is sold on that date. An investment is considered fully realized if it has zero holding valuation.

\begin{tabular}{lccccccc}
\hline \hline & & \multicolumn{5}{c}{$\begin{array}{l}\text { Financial performance of the portfolio of all equity invest- } \\
\text { ments with vintage years including and since... }\end{array}$} \\
\cline { 3 - 8 } & & 1961 & 1970 & 1980 & 1990 & 2000 & 2010 \\
\hline PME vs. MSCI Emerging Markets & 1988 & & & & 1.3 & 1.18 & 0.98 \\
PME vs. MSCI World & 1970 & & 1.21 & 1.26 & 1.23 & 1.12 & 0.78 \\
PME vs. S\&P 500 & 1957 & 1.15 & 1.13 & 1.16 & 1.14 & 1.07 & 0.7 \\
\hline Total value to paid-in (TVPI) & & 1.71 & 1.70 & 1.69 & 1.61 & 1.47 & 1.15 \\
\hline Number of investments & & 2,509 & 2,429 & 2,304 & 2,053 & 1,433 & 803 \\
Share of investments fully realized & & $69.20 \%$ & $68.20 \%$ & $66.40 \%$ & $62.50 \%$ & $47.50 \%$ & $25.80 \%$ \\
\hline
\end{tabular}


TABLE IV: Investment financial performance and investment size. Total cash deployed across 2,509 companies is classifed into investment size quartiles by decade. Panel A reports the cut offs for each quartile. Panel B reports the returns to a synthetic portfolio made up of only the investments in each quartile. For the PME vs. MSCI Emerging Markets, projects are included in the calculation if they have vintage years after 1988, when the index began. For the PME vs. MSCI World, projects are included if they have vintage years on or after 1970. For the PME vs. S\&P 500 , all projects are included.

\begin{tabular}{|c|c|c|c|c|}
\hline \multicolumn{5}{|c|}{ Panel A) Investment size cutoffs by decade (nominal \$ millions) } \\
\hline Time Period & $\begin{array}{l}\text { Bottom } \\
\text { Quartile }\end{array}$ & Median & $\begin{array}{l}\text { Top } \\
\text { Quartile }\end{array}$ & Mean \\
\hline $1959-69$ & 0.33 & 0.72 & 2.02 & 1.32 \\
\hline $1970-79$ & 0.35 & 0.88 & 2.00 & 1.85 \\
\hline $1980-89$ & 0.30 & 0.84 & 2.50 & 3.01 \\
\hline 1990-99 & 0.60 & 2.22 & 6.09 & 5.28 \\
\hline 2000-09 & 2.04 & 6.00 & 15.45 & 13.17 \\
\hline $2010-19$ & 4.00 & 10.00 & 21.76 & 19.49 \\
\hline \multicolumn{5}{|c|}{ Panel B) Portfolio performance by size quartile } \\
\hline Investment size & TVPI & $\begin{array}{l}\text { PME vs. } \\
\text { S\&P } 500\end{array}$ & $\begin{array}{l}\text { PME vs. } \\
\text { MSCI } \\
\text { World }\end{array}$ & $\begin{array}{l}\text { PME vs. } \\
\text { MSCI } \\
\text { Emerging } \\
\text { Markets }\end{array}$ \\
\hline 1st quartile (smallest) & 2.18 & 1.48 & 1.44 & 1.85 \\
\hline 2nd quartile & 1.83 & 1.16 & 1.2 & 1.26 \\
\hline 3rd quartile & 1.68 & 1.02 & 1.11 & 1.21 \\
\hline 4th quartile (largest) & 1.69 & 1.18 & 1.24 & 1.36 \\
\hline
\end{tabular}


TABLE V: Investment financial performance and market size. The dependent variable is the PME vs. S\&P500, winsorized at the 99th percentile. Independent variables are the population and GDP per capita of the country, on the year of the first cash flow associated with the investment. Panel A reports a linear regression with the constant not reported. Panel B reports the same regression, but with fixed effects for 22 subsectors that partition IFC's four sectoral departments: Manufacturing, Agriculture and Services; Financial Institutions; Infrastructure; and Collective Investment Vehicles (funds). Panel $\mathrm{C}$ reports the same regression, excluding the five most recent vintage years, whose performance is disproportionately determined by mark to market valuations. Standard errors are clustered at the country-year. $* * * \mathrm{p}<0.01, * * \mathrm{p}<0.05, * \mathrm{p}<0.1$

\begin{tabular}{|c|c|c|c|c|c|c|}
\hline & (1) & (2) & (3) & (4) & (5) & (6) \\
\hline & & \multicolumn{5}{|c|}{ Quantile Regressions } \\
\hline & OLS & 0.1 & 0.25 & 0.5 & 0.75 & 0.9 \\
\hline & PME & PME & PME & PME & PME & PME \\
\hline \multicolumn{7}{|c|}{ Panel A) Baseline specification } \\
\hline \multirow[t]{2}{*}{ Ln(Population) } & 0.028 & 0.003 & 0.010 & $0.019^{* *}$ & $0.023^{*}$ & 0.025 \\
\hline & $(0.021)$ & $(0.005)$ & $(0.008)$ & $(0.009)$ & $(0.014)$ & $(0.026)$ \\
\hline \multirow[t]{2}{*}{ Ln(GDP per capita) } & 0.025 & 0.003 & $0.033^{* *}$ & $0.050^{* *}$ & 0.041 & -0.068 \\
\hline & $(0.044)$ & $(0.010)$ & $(0.013)$ & $(0.020)$ & $(0.029)$ & $(0.048)$ \\
\hline R-squared (pseudo) & 0.096 & 0.035 & 0.060 & 0.072 & 0.096 & 0.164 \\
\hline Observations & 2,069 & 2,069 & 2,069 & 2,069 & 2,069 & 2,069 \\
\hline Sample & Full & Full & Full & Full & Full & Full \\
\hline Vintage year fixed effects & Yes & Yes & Yes & Yes & Yes & Yes \\
\hline Sector fixed effects & No & No & No & No & No & No \\
\hline \multicolumn{7}{|c|}{ Panel B) Baseline specification with sector fixed effects } \\
\hline \multirow[t]{2}{*}{ Ln(Population) } & $0.038^{*}$ & 0.004 & 0.010 & $0.016^{*}$ & 0.022 & $0.050 * *$ \\
\hline & $(0.021)$ & $(0.005)$ & $(0.007)$ & $(0.009)$ & $(0.016)$ & $(0.024)$ \\
\hline \multirow[t]{2}{*}{ Ln(GDP per capita) } & 0.033 & 0.004 & 0.019 & $0.055^{* * *}$ & 0.053 & 0.045 \\
\hline & $(0.044)$ & $(0.009)$ & $(0.012)$ & $(0.020)$ & $(0.037)$ & $(0.060)$ \\
\hline R-squared (pseudo) & 0.131 & 0.047 & 0.085 & 0.091 & 0.117 & 0.202 \\
\hline Observations & 2,069 & 2,069 & 2,069 & 2,069 & 2,069 & 2,069 \\
\hline Sample & Full & Full & Full & Full & Full & Full \\
\hline Vintage year fixed effects & Yes & Yes & Yes & Yes & Yes & Yes \\
\hline Sector fixed effects & Yes & Yes & Yes & Yes & Yes & Yes \\
\hline \multicolumn{7}{|c|}{ Panel C) Baseline specification with sector fixed effects, including only vintage years $<2015$} \\
\hline \multirow[t]{2}{*}{ Ln(Population) } & 0.036 & 0.002 & 0.005 & 0.017 & 0.023 & $0.076 * *$ \\
\hline & $(0.024)$ & $(0.006)$ & $(0.007)$ & $(0.011)$ & $(0.018)$ & $(0.039)$ \\
\hline \multirow[t]{2}{*}{ Ln(GDP per capita) } & 0.045 & 0.004 & 0.022 & $0.067 * * *$ & $0.068^{*}$ & 0.050 \\
\hline & $(0.050)$ & $(0.010)$ & $(0.013)$ & $(0.021)$ & $(0.038)$ & $(0.094)$ \\
\hline R-squared (pseudo) & 0.134 & 0.026 & 0.068 & 0.093 & 0.121 & 0.202 \\
\hline Observations & 1,837 & 1,837 & 1,837 & 1,837 & 1,837 & 1,837 \\
\hline Sample & Pre-2015 & Pre-2015 & Pre-2015 & Pre-2015 & Pre-2015 & Pre-2015 \\
\hline Vintage year fixed effects & Yes & Yes & Yes & Yes & Yes & Yes \\
\hline Sector fixed effects & Yes & Yes & Yes & Yes & Yes & Yes \\
\hline
\end{tabular}


के

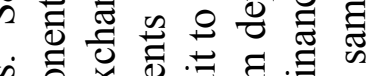

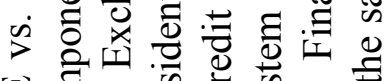

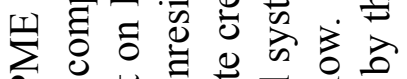

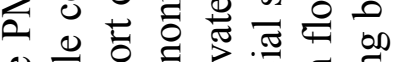

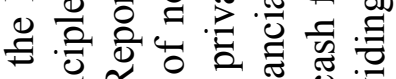
.

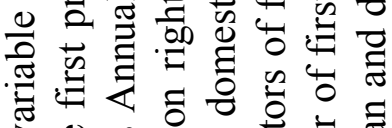
>

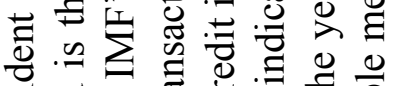

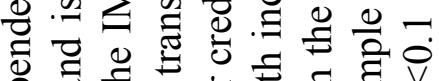

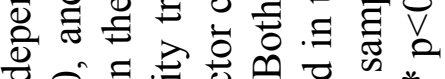

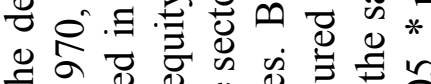

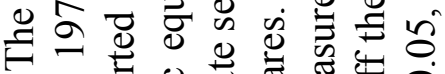

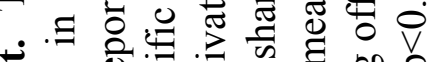
t)

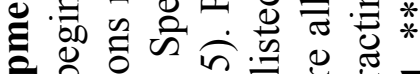

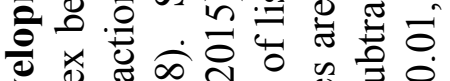

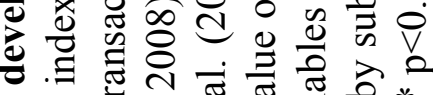

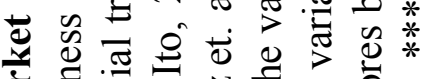

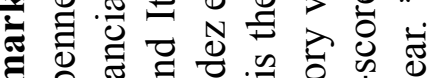

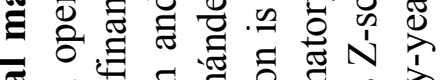

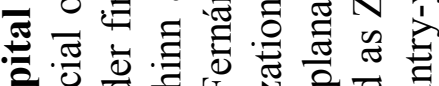

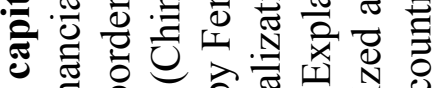

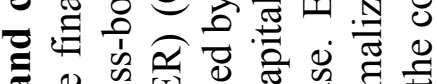
的

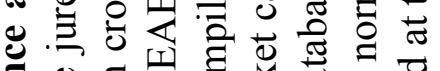
政

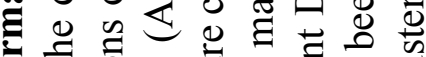
s.

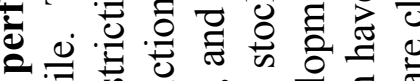
ส

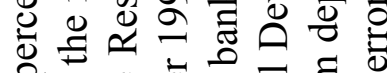

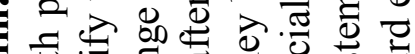

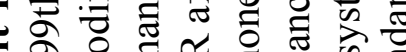



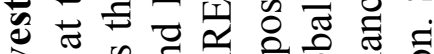

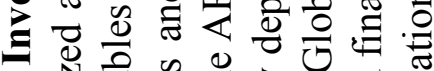

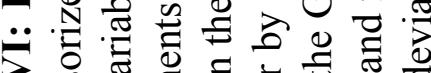
되류 닥 थ

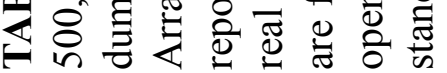

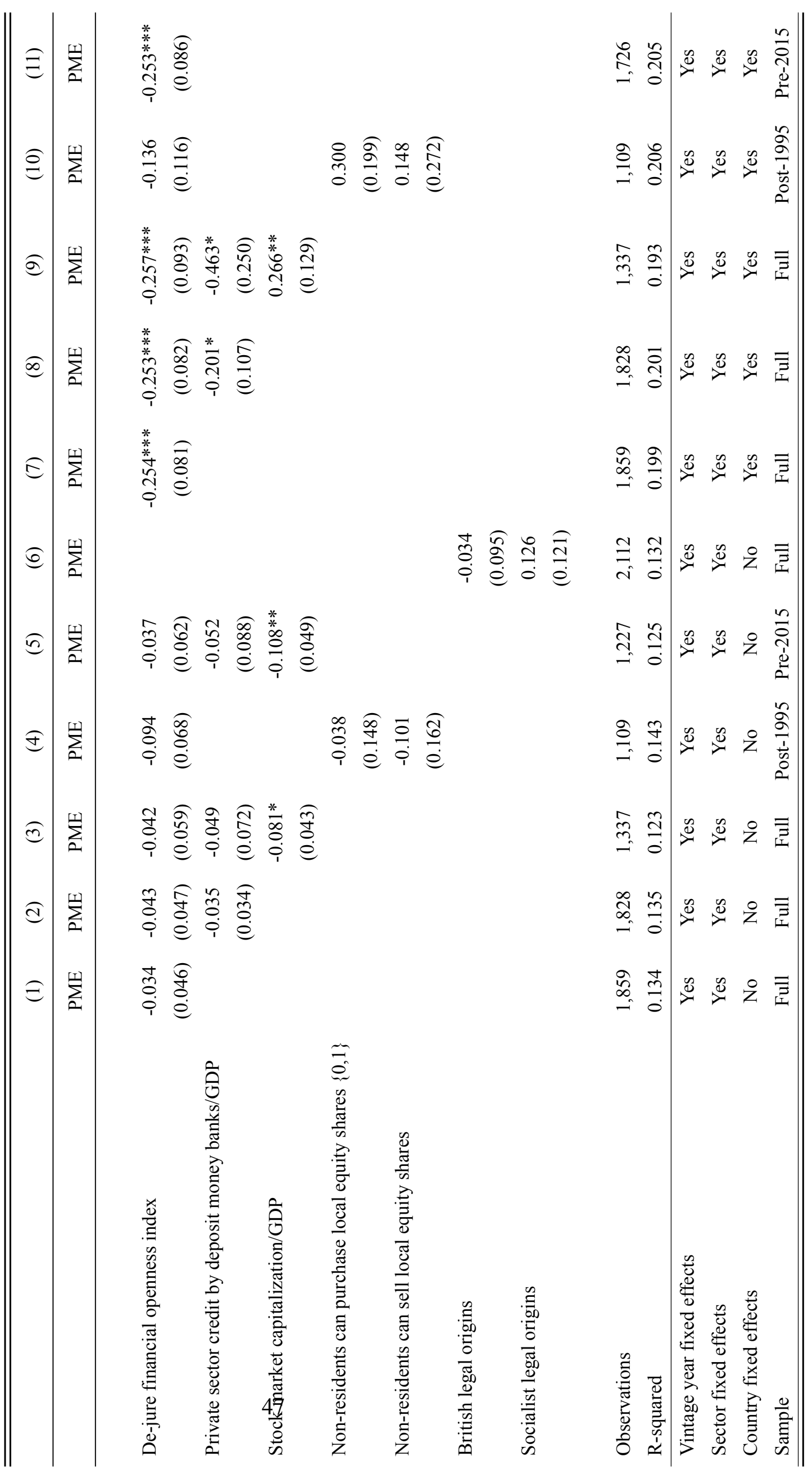


TABLE VII: Investment financial performance and country-level risk factors in year before first cash flow. The dependent variable is the PME with respect to the S\&P 500, winsorized at the 99th percentile. Explanatory variables have been normalized as Z-scores by subtracting off the sample mean and dividing by the sample standard deviation. Standard errors are clustered at the country-year. $* * * \mathrm{p}<0.01, * * \mathrm{p}<0.05, * \mathrm{p}<0.1$

\begin{tabular}{|c|c|c|c|c|c|c|}
\hline & (1) & (2) & (3) & (4) & $(5)$ & (6) \\
\hline & PME & PME & PME & PME & PME & PME \\
\hline \multirow[t]{2}{*}{ Political Risk (PRS Group) } & -0.011 & & & & & 0.080 \\
\hline & $(0.067)$ & & & & & $(0.063)$ \\
\hline \multirow[t]{2}{*}{ Economic Freedom (Heritage Foundation) } & & $-0.081 *$ & & & & 0.032 \\
\hline & & $(0.047)$ & & & & $(0.074)$ \\
\hline \multirow[t]{2}{*}{ Corruption Perception (Transparency Int'l) } & & & -0.034 & & & -0.059 \\
\hline & & & $(0.053)$ & & & $(0.057)$ \\
\hline \multirow[t]{2}{*}{ Economic Fitness (Cristelli et al., 2017) } & & & & 0.066 & & 0.062 \\
\hline & & & & $(0.042)$ & & $(0.066)$ \\
\hline \multirow[t]{2}{*}{ Ease of Doing Business Distance to Frontier (World Bank) } & & & & & 0.037 & 0.032 \\
\hline & & & & & $(0.036)$ & $(0.088)$ \\
\hline R-squared & 0.138 & 0.127 & 0.139 & 0.037 & 0.091 & 0.117 \\
\hline Observations & 1,009 & 1,029 & 1,031 & 707 & 446 & 392 \\
\hline Sample & Full & Full & Full & Full & Full & Full \\
\hline Vintage year fixed effects & Yes & Yes & Yes & Yes & Yes & Yes \\
\hline Sector fixed effects & Yes & Yes & Yes & Yes & Yes & Yes \\
\hline
\end{tabular}


TABLE VIII: Investment financial performance and macroeconomic variables recorded in the year before the first cash flow. The dependent variable is the PME with respect to the S\&P 500, winsorized at the 99th percentile. All independent variables are changes between the year of first cash flow and the previous year. Real GDP growth (in USD), inflation (change in LC GDP deflator) and currency depreciation (change in USD/LC) are from the WDI. Central government debt is from the International Financial Statistics. Sovereign rating is the (reverse) composite index provided by Oxford Economics based on the average of the sovereign ratings provided by Moody's, S\&P and Fitch, ranging from 1 to 20 , where 20 is the worst possible credit rating. Higher values indicate higher credit risk. Regression constant is not reported. Standard errors are clustered at the country-year.

$* * * \mathrm{p}<0.01, * * \mathrm{p}<0.05, * \mathrm{p}<0.1$

\begin{tabular}{|c|c|c|c|c|c|c|c|c|}
\hline & (1) & (2) & (3) & (4) & (5) & (6) & (7) & (8) \\
\hline & PME & PME & PME & PME & PME & PME & PME & PME \\
\hline \multirow[t]{2}{*}{ Real GDP growth rate } & 1.211 & & & & & $1.653^{*}$ & 1.966 & 0.444 \\
\hline & $(0.969)$ & & & & & $(0.991)$ & $(1.203)$ & $(1.323)$ \\
\hline \multirow[t]{2}{*}{ Inflation rate } & & 0.140 & & & & 0.017 & 0.021 & 0.745 \\
\hline & & $(0.126)$ & & & & $(0.483)$ & $(0.583)$ & $(0.618)$ \\
\hline \multirow[t]{2}{*}{ Currency depreciation rate } & & & 0.129 & & & 0.138 & 0.134 & -0.749 \\
\hline & & & $(0.128)$ & & & $(0.494)$ & $(0.602)$ & $(0.636)$ \\
\hline \multirow[t]{2}{*}{ Central government debt ( $\%$ GDP) } & & & & -0.001 & & & -0.001 & -0.001 \\
\hline & & & & $(0.001)$ & & & $(0.001)$ & $(0.003)$ \\
\hline \multirow[t]{2}{*}{ Sovereign rating index } & & & & & -0.000 & & & 0.026 \\
\hline & & & & & $(0.018)$ & & & $(0.027)$ \\
\hline R-squared & 0.107 & 0.107 & 0.106 & 0.129 & 0.094 & 0.126 & 0.158 & 0.146 \\
\hline Observations & 2,065 & 2,066 & 2,105 & 1,668 & 1,336 & 2,062 & 1,641 & 1,073 \\
\hline Sample & Full & Full & Full & Full & Full & Full & Full & Full \\
\hline Vintage year fixed effects & Yes & Yes & Yes & Yes & Yes & Yes & Yes & Yes \\
\hline Sector fixed effects & Yes & Yes & Yes & Yes & Yes & Yes & Yes & Yes \\
\hline
\end{tabular}


TABLE IX: Investment financial performance and macroeconomics over the life of the investment. The dependent variable is the PME with respect to the S\&P 500, winsorized at the 99th percentile. Explanatory variables are measured as annualized changes from the year of first cash flow to the date of the last cash flow. Real GDP growth (in USD), inflation (change in LC GDP deflator) and currency depreciation (change in USD/LC) are from the WDI. Central government debt is from the International Financial Statistics. Sovereign rating is the (reverse) composite index provided by Oxford Economics based on the average of the sovereign ratings provided by Moody's, S\&P and Fitch, ranging from 1 to 20 , where 20 is the worst possible credit rating. Higher values indicate higher credit risk. Regression constant is not reported. Standard errors are clustered at the country-year. $* * * \mathrm{p}<0.01, * * \mathrm{p}<0.05, * \mathrm{p}<0.1$

\begin{tabular}{|c|c|c|c|c|c|c|c|c|}
\hline & (1) & (2) & (3) & (4) & (5) & (6) & (7) & (8) \\
\hline & PME & PME & PME & PME & PME & PME & PME & PME \\
\hline \multirow[t]{2}{*}{ Real GDP growth } & $6.620 * * *$ & & & $4.306^{*}$ & & & 2.869 & -3.580 \\
\hline & $(2.435)$ & & & $(2.491)$ & & & $(2.636)$ & $(4.503)$ \\
\hline \multirow[t]{2}{*}{ Currency depreciation } & & $-0.355^{*}$ & & $-3.945^{* * *}$ & & & $-3.670 * * *$ & $-4.103 * *$ \\
\hline & & $(0.192)$ & & $(1.158)$ & & & $(1.376)$ & (1.619) \\
\hline \multirow[t]{2}{*}{ Inflation } & & & -0.202 & $3.713 * * *$ & & & $3.341 * *$ & $3.503 * *$ \\
\hline & & & $(0.192)$ & $(1.145)$ & & & $(1.361)$ & $(1.647)$ \\
\hline \multirow[t]{2}{*}{ Central government debt ( $\%$ GDP) } & & & & & $-0.020^{*}$ & & -0.004 & 0.025 \\
\hline & & & & & $(0.012)$ & & $(0.012)$ & $(0.028)$ \\
\hline \multirow[t]{2}{*}{ Sovereign rating index } & & & & & & $-0.378 * *$ & & -0.430 \\
\hline & & & & & & $(0.166)$ & & $(0.349)$ \\
\hline R-squared & 0.149 & 0.143 & 0.145 & 0.155 & 0.181 & 0.122 & 0.188 & 0.192 \\
\hline Observations & 1,393 & 1,417 & 1,392 & 1,391 & 1,109 & 1,310 & 1,095 & 623 \\
\hline Sample & Full & Full & Full & Full & Full & Full & Full & Full \\
\hline Vintage year fixed effects & Yes & Yes & Yes & Yes & Yes & Yes & Yes & Yes \\
\hline Sector fixed effects & Yes & Yes & Yes & Yes & Yes & Yes & Yes & Yes \\
\hline
\end{tabular}


TABLE X: Investment financial performance and holding duration Duration is measured as the number of years between the first and last cash flow. Columns 3 and 4 include only investments that have been realized, and have a current holding valuation equal to zero. Standard errors are clustered at the country-year. ${ }^{* * *} \mathrm{p}<0.01,{ }^{* *} \mathrm{p}<0.05,{ }^{*} \mathrm{p}<0.1$

\begin{tabular}{lcccc}
\hline \hline & $(1)$ & $(2)$ & $(3)$ & $(4)$ \\
\hline & PME & PME & PME & PME \\
\hline Duration & $0.040^{* * *}$ & & $0.045^{* * *}$ & \\
& $(0.009)$ & & $(0.011)$ & \\
Duration X 1(Duration $<5)$ & & $0.090^{* *}$ & & $0.092^{* *}$ \\
& & $(0.038)$ & & $(0.037)$ \\
Duration X 1 $(5 \leq$ Duration $<10)$ & & $0.089^{* * *}$ & & $0.091^{* * *}$ \\
& & $(0.020)$ & & $(0.022)$ \\
Duration X 1 $(10 \leq$ Duration) & & $0.046^{* * *}$ & & $0.050^{* * *}$ \\
& & $(0.010)$ & & $(0.011)$ \\
R-squared & & & & 0.127 \\
Observations & 0.120 & 0.124 & 0.124 & 0.736 \\
\hline Sample & 2,509 & 2,509 & 1,736 & 1,736 \\
\hline Vintage year fixed effects & Full & Full & Realized & Realized \\
Sector fixed effects & Yes & Yes & Yes & Yes \\
\hline & Yes & Yes & Yes & Yes \\
\hline
\end{tabular}


APPENDIX A: Historical IFC Financial Statements and Ratios. Balance sheet and income statement values are as reported in the annual report, including revisions. Total assets prior to 1974 do not include the undrawn portion of a loan from the International Bank for Reconstruction and Development. Values of assets prior to 2001 are not directly comparable with those after due to a change in accounting standards requiring derivatives to be held at fair rather than book value (FAS No. 133) Return on equity is net income/total capital. Return on assets is net income/total assets. The leverage ratio is total assets/total capital. The expense ratio is non-interest expense/total assets.

\begin{tabular}{|c|c|c|c|c|c|c|c|c|}
\hline \multirow{3}{*}{ Fiscal Year } & \multicolumn{2}{|c|}{ Balance Sheet } & \multicolumn{2}{|c|}{ Income Statement } & \multicolumn{4}{|c|}{ Financial Ratios } \\
\hline & $\begin{array}{l}\text { Total } \\
\text { Capital }\end{array}$ & Total Assets & $\begin{array}{l}\text { Net } \\
\text { Income }\end{array}$ & $\begin{array}{l}\text { Non- } \\
\text { Interest } \\
\text { Expense }\end{array}$ & Return on Equity & Return on Assets & Leverage & Expense \\
\hline & $\$ \mathrm{Mn}$ & $\$ M n$ & $\$ \mathrm{Mn}$ & $\$ \mathrm{Mn}$ & & & & \\
\hline 1957 & 93.5 & 93.6 & 1.7 & 0.7 & $1.79 \%$ & $1.79 \%$ & 1.001 & $0.78 \%$ \\
\hline 1958 & 97.3 & 97.4 & 2.4 & 1.1 & $2.42 \%$ & $2.42 \%$ & 1.001 & $1.18 \%$ \\
\hline 1959 & 99.4 & 99.5 & 1.7 & 1.4 & $1.75 \%$ & $1.75 \%$ & 1.001 & $1.42 \%$ \\
\hline 1960 & 104.3 & 104.5 & 2.1 & 1.7 & $1.99 \%$ & $1.99 \%$ & 1.002 & $1.63 \%$ \\
\hline 1961 & 107.2 & 107.8 & 2.4 & 2.0 & $2.20 \%$ & $2.19 \%$ & 1.006 & $1.87 \%$ \\
\hline 1962 & 109.8 & 111.6 & 2.6 & 2.0 & $2.40 \%$ & $2.36 \%$ & 1.016 & $1.77 \%$ \\
\hline 1963 & 115.2 & 115.4 & 3.3 & 2.2 & $2.88 \%$ & $2.87 \%$ & 1.001 & $1.87 \%$ \\
\hline 1964 & 119.3 & 119.4 & 2.9 & 2.5 & $2.44 \%$ & $2.44 \%$ & 1.001 & $2.06 \%$ \\
\hline 1965 & 122.2 & 122.3 & 3.0 & 2.7 & $2.46 \%$ & $2.46 \%$ & 1.001 & $2.23 \%$ \\
\hline 1966 & 128.2 & 128.4 & 4.4 & 3.1 & $3.40 \%$ & $3.40 \%$ & 1.001 & $2.38 \%$ \\
\hline 1967 & 134.8 & 134.9 & 6.0 & 3.2 & $4.47 \%$ & $4.47 \%$ & 1.001 & $2.37 \%$ \\
\hline 1968 & 142.9 & 143.2 & 6.2 & 3.5 & $4.37 \%$ & $4.36 \%$ & 1.002 & $2.46 \%$ \\
\hline 1969 & 155.2 & 156.0 & 7.5 & 4.1 & $4.81 \%$ & $4.78 \%$ & 1.005 & $2.66 \%$ \\
\hline 1970 & 165.8 & 184.1 & 10.3 & 5.4 & $6.18 \%$ & $5.57 \%$ & 1.111 & $2.91 \%$ \\
\hline 1971 & 172.1 & 237.0 & 6.2 & 6.5 & $3.58 \%$ & $2.60 \%$ & 1.377 & $2.74 \%$ \\
\hline 1972 & 179.7 & 264.7 & 8.0 & 7.1 & $4.43 \%$ & $3.00 \%$ & 1.473 & $2.67 \%$ \\
\hline 1973 & 166.7 & 278.9 & 4.2 & 7.5 & $2.50 \%$ & $1.49 \%$ & 1.673 & $2.70 \%$ \\
\hline 1974 & 172.5 & 355.5 & 5.9 & 9.2 & $3.44 \%$ & $1.67 \%$ & 2.060 & $2.58 \%$ \\
\hline 1975 & 178.2 & 457.6 & 5.4 & 10.4 & $3.03 \%$ & $1.18 \%$ & 2.568 & $2.28 \%$ \\
\hline 1976 & 186.7 & 523.7 & 7.7 & 11.4 & $4.12 \%$ & $1.47 \%$ & 2.805 & $2.18 \%$ \\
\hline 1977 & 195.7 & 653.8 & 8.9 & 13.1 & $4.55 \%$ & $1.36 \%$ & 3.340 & $2.01 \%$ \\
\hline 1978 & 243.8 & 720.8 & 12.5 & 16.2 & $5.13 \%$ & $1.73 \%$ & 2.957 & $2.24 \%$ \\
\hline 1979 & 347.7 & 819.7 & 19.2 & 20.9 & $5.52 \%$ & $2.34 \%$ & 2.357 & $2.55 \%$ \\
\hline 1980 & 446.4 & 907.8 & 20.7 & 26.5 & $4.63 \%$ & $2.28 \%$ & 2.034 & $2.92 \%$ \\
\hline 1981 & 551.3 & $1,084.8$ & 19.5 & 34.3 & $3.53 \%$ & $1.80 \%$ & 1.968 & $3.16 \%$ \\
\hline 1982 & 678.1 & $1,233.4$ & 21.6 & 39.3 & $3.18 \%$ & $1.75 \%$ & 1.819 & $3.18 \%$ \\
\hline 1983 & 747.6 & $1,313.8$ & 23.1 & 43.1 & $3.08 \%$ & $1.75 \%$ & 1.757 & $3.28 \%$ \\
\hline 1984 & 774.3 & $1,389.9$ & 26.3 & 45.0 & $3.40 \%$ & $1.89 \%$ & 1.795 & $3.24 \%$ \\
\hline 1985 & 804.2 & $1,672.8$ & 28.3 & 51.5 & $3.52 \%$ & $1.69 \%$ & 2.080 & $3.08 \%$ \\
\hline 1986 & 885.6 & $2,236.4$ & 25.4 & 60.2 & $2.87 \%$ & $1.14 \%$ & 2.525 & $2.69 \%$ \\
\hline 1987 & $1,059.2$ & $2,814.1$ & 53.8 & 63.7 & $5.08 \%$ & $1.91 \%$ & 2.657 & $2.27 \%$ \\
\hline 1988 & $1,288.5$ & $3,427.0$ & 100.6 & 41.6 & $7.80 \%$ & $2.93 \%$ & 2.660 & $2.09 \%$ \\
\hline
\end{tabular}




\begin{tabular}{|c|c|c|c|c|c|c|c|c|}
\hline \multirow{3}{*}{ Fiscal Year } & \multicolumn{2}{|c|}{ Balance Sheet } & \multicolumn{2}{|c|}{ Income Statement } & \multicolumn{4}{|c|}{ Financial Ratios } \\
\hline & $\begin{array}{l}\text { Total } \\
\text { Capital }\end{array}$ & Total Assets & $\begin{array}{l}\text { Net } \\
\text { Income }\end{array}$ & $\begin{array}{l}\text { Non- } \\
\text { Interest } \\
\text { Expense }\end{array}$ & Return on Equity & Return on Assets & Leverage & Expense \\
\hline & $\$ M n$ & $\$ M n$ & $\$ \mathrm{Mn}$ & $\$ M n$ & & & & \\
\hline 1989 & $1,582.6$ & $4,006.1$ & 196.5 & 76.8 & $12.41 \%$ & $4.90 \%$ & 2.531 & $1.92 \%$ \\
\hline 1990 & $1,864.1$ & $5,606.3$ & 157.0 & 105.9 & $8.42 \%$ & $2.80 \%$ & 3.008 & $1.89 \%$ \\
\hline 1991 & $2,104.0$ & $6,648.2$ & 165.9 & 119.7 & $7.88 \%$ & $2.49 \%$ & 3.160 & $1.80 \%$ \\
\hline 1992 & $2,389.3$ & $8,132.7$ & 180.2 & 139.7 & $7.54 \%$ & $2.22 \%$ & 3.404 & $1.72 \%$ \\
\hline 1993 & $2,702.4$ & $8,913.4$ & 141.7 & 163.2 & $5.25 \%$ & $1.59 \%$ & 3.298 & $1.83 \%$ \\
\hline 1994 & $3,198.1$ & $14,722.8$ & 258.2 & 175.2 & $8.07 \%$ & $1.75 \%$ & 4.604 & $1.19 \%$ \\
\hline 1995 & $3,602.8$ & $18,227.6$ & 188.0 & 171.0 & $5.22 \%$ & $1.03 \%$ & 5.059 & $0.94 \%$ \\
\hline 1996 & $4,158.2$ & $22,640.2$ & 345.8 & 185.4 & $8.32 \%$ & $1.53 \%$ & 5.445 & $0.82 \%$ \\
\hline 1997 & $4,736.9$ & $28,974.7$ & 431.9 & 204.5 & $9.12 \%$ & $1.49 \%$ & 6.117 & $0.71 \%$ \\
\hline 1998 & $5,084.3$ & $31,620.7$ & 245.8 & 218.0 & $4.83 \%$ & $0.78 \%$ & 6.219 & $0.69 \%$ \\
\hline 1999 & $5,344.2$ & $33,456.2$ & 249.3 & 258.0 & $4.66 \%$ & $0.75 \%$ & 6.260 & $0.77 \%$ \\
\hline 2000 & $5,733.0$ & $38,719.0$ & 380.0 & 265.0 & $6.63 \%$ & $0.98 \%$ & 6.754 & $0.68 \%$ \\
\hline 2001 & $6,095.0$ & $26,170.0$ & 345.0 & 304.0 & $5.66 \%$ & $1.32 \%$ & 4.294 & $1.16 \%$ \\
\hline 2002 & $6,304.0$ & $27,739.0$ & 215.0 & 327.0 & $3.41 \%$ & $0.78 \%$ & 4.400 & $1.18 \%$ \\
\hline 2003 & $6,789.0$ & $31,543.0$ & 487.0 & 332.0 & $7.17 \%$ & $1.54 \%$ & 4.646 & $1.05 \%$ \\
\hline 2004 & $7,782.0$ & $32,361.0$ & 993.0 & 360.0 & $12.76 \%$ & $3.07 \%$ & 4.158 & $1.11 \%$ \\
\hline 2005 & $9,798.0$ & $39,560.0$ & $2,015.0$ & 403.0 & $20.57 \%$ & $5.09 \%$ & 4.038 & $1.02 \%$ \\
\hline 2006 & $11,076.0$ & $38,420.0$ & $1,264.0$ & 436.0 & $11.41 \%$ & $3.29 \%$ & 3.469 & $1.13 \%$ \\
\hline 2007 & $14,017.0$ & $40,599.0$ & $2,490.0$ & 482.0 & $17.76 \%$ & $6.13 \%$ & 2.896 & $1.19 \%$ \\
\hline 2008 & $18,261.0$ & $49,471.0$ & $1,547.0$ & 549.0 & $8.47 \%$ & $3.13 \%$ & 2.709 & $1.11 \%$ \\
\hline 2009 & $16,122.0$ & $51,483.0$ & -151.0 & 582.0 & $-0.94 \%$ & $-0.29 \%$ & 3.193 & $1.13 \%$ \\
\hline 2010 & $18,359.0$ & $61,075.0$ & $1,746.0$ & 664.0 & $9.51 \%$ & $2.86 \%$ & 3.327 & $1.09 \%$ \\
\hline 2011 & $20,279.0$ & $68,490.0$ & $1,579.0$ & 700.0 & $7.79 \%$ & $2.31 \%$ & 3.377 & $1.02 \%$ \\
\hline 2012 & $20,580.0$ & $75,761.0$ & $1,328.0$ & 798.0 & $6.45 \%$ & $1.75 \%$ & 3.681 & $1.05 \%$ \\
\hline 2013 & $22,275.0$ & $77,525.0$ & $1,018.0$ & 845.0 & $4.57 \%$ & $1.31 \%$ & 3.480 & $1.09 \%$ \\
\hline 2014 & $23,990.0$ & $84,130.0$ & $1,483.0$ & 888.0 & $6.18 \%$ & $1.76 \%$ & 3.507 & $1.06 \%$ \\
\hline 2015 & $24,426.0$ & $87,548.0$ & 445.0 & 901.0 & $1.82 \%$ & $0.51 \%$ & 3.584 & $1.03 \%$ \\
\hline 2016 & $22,766.0$ & $90,434.0$ & -33.0 & 933.0 & $-0.14 \%$ & $-0.04 \%$ & 3.972 & $1.03 \%$ \\
\hline 2017 & $25,053.0$ & $92,254.0$ & $1,418.0$ & 962.0 & $5.66 \%$ & $1.54 \%$ & 3.682 & $1.04 \%$ \\
\hline 2018 & $26,136.0$ & $94,272.0$ & $1,280.0$ & $1,029.0$ & $4.90 \%$ & $1.36 \%$ & 3.607 & $1.09 \%$ \\
\hline 2019 & $27,606.0$ & $99,257.0$ & 93.0 & $1,355.0$ & $0.34 \%$ & $0.09 \%$ & 3.595 & $1.37 \%$ \\
\hline
\end{tabular}


APPENDIX B: Equity investments by region and sector. Regions follow the World Bank Group regional classifications as of 2019. Collective investment vehicles are private equity funds managed by an institution other than IFC.

$1961-69 \quad 1970-79 \quad 1980-89 \quad 1990-99 \quad 2000-09 \quad 2010-19 \quad$ TOTAL

Panel A) Count of investments by region

\begin{tabular}{lccccccc} 
Latin America and Caribbean & 34 & 33 & 71 & 143 & 119 & 158 & 558 \\
East Asia and Pacific & 7 & 29 & 53 & 97 & 122 & 154 & 462 \\
Sub-Saharan Africa & 13 & 20 & 58 & 117 & 95 & 149 & 452 \\
South Asia & 11 & 7 & 27 & 81 & 106 & 147 & 379 \\
Europe and Central Asia & 5 & 15 & 13 & 123 & 118 & 77 & 351 \\
Middle East and North Africa & 6 & 16 & 21 & 51 & 44 & 65 & 203 \\
World & 4 & 5 & 8 & 8 & 26 & 53 & 104 \\
TOTAL & 80 & 125 & 251 & 620 & 630 & 803 & 2,509 \\
\hline
\end{tabular}

Panel B) Count of investments by sector

\begin{tabular}{|c|c|c|c|c|c|c|c|}
\hline Finance and Insurance & 22 & 20 & 40 & 133 & 222 & 193 & 630 \\
\hline Collective Investment Vehicles & - & 2 & 26 & 136 & 137 & 231 & 532 \\
\hline Oil, Gas and Mining & 2 & 6 & 28 & 40 & 44 & 43 & 163 \\
\hline Industrial and Consumer Products & 8 & 7 & 32 & 31 & 15 & 16 & 109 \\
\hline Chemicals & 8 & 8 & 24 & 30 & 23 & 15 & 108 \\
\hline Food and Beverages & 4 & 4 & 22 & 37 & 14 & 17 & 98 \\
\hline Electric Power & 1 & - & - & 26 & 11 & 58 & 96 \\
\hline Nonmetallic Mineral Product Manufacturing & 8 & 18 & 14 & 28 & 12 & 8 & 88 \\
\hline Agriculture and Forestry & 2 & 6 & 19 & 13 & 16 & 24 & 80 \\
\hline Transportation and Warehousing & - & 2 & 6 & 23 & 16 & 33 & 80 \\
\hline Textiles, Apparel and Leather & 10 & 19 & 10 & 26 & 3 & 2 & 70 \\
\hline Information & 1 & - & 1 & 23 & 20 & 23 & 68 \\
\hline Accommodation and Tourism Services & 3 & 11 & 10 & 23 & 9 & 7 & 63 \\
\hline Professional, Scientific and Technical Services & - & - & 3 & 5 & 30 & 24 & 62 \\
\hline Health Care & - & - & - & 9 & 15 & 29 & 53 \\
\hline Pulp and Paper & 5 & 8 & 6 & 13 & 7 & 4 & 43 \\
\hline Primary Metals & 6 & 10 & 7 & 10 & 4 & 1 & 38 \\
\hline Utilities & - & - & - & 1 & 10 & 20 & 31 \\
\hline Construction and Real Estate & - & - & - & 4 & 4 & 19 & 27 \\
\hline Education Services & - & - & 1 & - & 7 & 19 & 27 \\
\hline Wholesale and Retail Trade & - & - & - & 5 & 7 & 15 & 27 \\
\hline Plastics and Rubber & - & 4 & 2 & 4 & 4 & 2 & 16 \\
\hline TOTAL & 80 & 125 & 251 & 620 & 630 & 803 & 2,509 \\
\hline
\end{tabular}




\begin{abstract}
APPENDIX C: Equity investment financial performance in emerging market and developing economies. In the weighted average, each investment is weighted by the share of cumulative contributions in that that vintage year. Before calculation of averages, variables have been winsorized at the 99th percentile, for consistency with the sample used in the regressions. Realized investments are those with zero holding valuation as of June 30, 2019.
\end{abstract}

\begin{tabular}{|c|c|c|c|c|c|c|c|c|c|}
\hline \multirow{2}{*}{ Vintage Years } & \multirow{2}{*}{ Investments } & \multirow{2}{*}{ Realized Investments } & \multirow{2}{*}{ Duration** } & \multicolumn{3}{|c|}{ PME S\&P 500} & \multicolumn{3}{|c|}{ TVPI } \\
\hline & & & & Average & Median & $\begin{array}{l}\text { Weighted } \\
\text { Average }\end{array}$ & Average & Median & $\begin{array}{l}\text { Weighted } \\
\text { Average }\end{array}$ \\
\hline 1961-69 & 80 & $100.0 \%$ & 17.4 & 1.44 & 1.02 & 1.35 & 3.18 & 1.84 & 2.75 \\
\hline 1970-79 & 125 & $100.0 \%$ & 14.0 & 0.90 & 0.51 & 0.94 & 3.22 & 1.37 & 3.51 \\
\hline 1980-89 & 251 & $98.8 \%$ & 11.5 & 0.98 & 0.45 & 1.17 & 2.90 & 1.21 & 3.30 \\
\hline 1990-99 & 620 & $97.3 \%$ & 9.3 & 1.34 & 0.65 & 1.39 & 2.47 & 1.19 & 2.54 \\
\hline 2000-09 & 630 & $75.1 \%$ & 8.2 & 1.60 & 0.87 & 1.84 & 2.32 & 1.26 & 2.59 \\
\hline 2010-19 & 803 & $25.8 \%$ & 4.5 & 0.81 & 0.74 & 0.84 & 1.23 & 1.00 & 1.25 \\
\hline ALL & 2,509 & $69.1 \%$ & 8.2 & 1.18 & 0.72 & 1.26 & 2.14 & 1.13 & 2.56 \\
\hline
\end{tabular}

**Duration is defined as the average years between first and final cash flow or positive valuation 


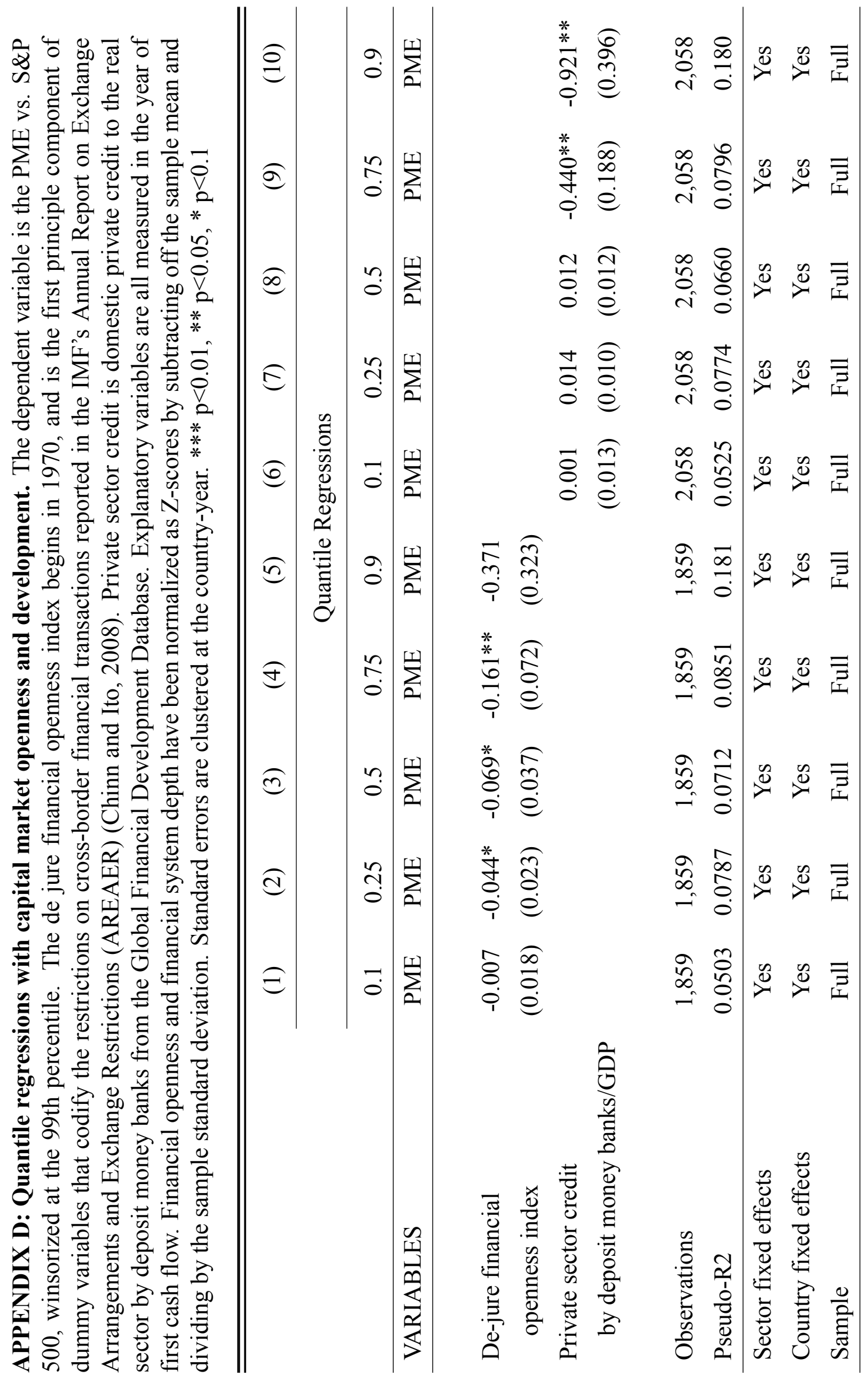

